Experimental procedures:

\title{
Compound 6a:
}<smiles>Clc1nc(NCc2ccccn2)c2c(-c3ccccc3)cccc2n1</smiles>

$6 a$

To 4-bromoindoline-2,3-dione ( $8.94 \mathrm{~g}, 39.6 \mathrm{mmol}$ ) was added $1.0 \mathrm{M}$ sodium hydroxide ( $40 \mathrm{~mL}, 120 \mathrm{mmol})$. The mixture was heated to $80^{\circ} \mathrm{C}$ then $20 \%$ hydrogen peroxide $(9 \mathrm{~mL}, 88 \mathrm{mmol}$ ) was added slowly over $15 \mathrm{~min}$ (caution: a strong exotherm was observed upon reagent addition). The mixture was then stirred at $80^{\circ} \mathrm{C}$ for $1 \mathrm{~h}$ then cooled in an ice bath. Concentrated $\mathrm{HCl}$ was added cautiously to the residue until the $\mathrm{pH}$ of the mixture was 4-5 and the mixture was then concentrated to dryness and $\mathrm{MeOH}(150 \mathrm{~mL})$ was added. The resulting suspension stirred for $15 \mathrm{~min}$ and then filtered. The filtrate was concentrated to dryness and dried under vacuum for $14 \mathrm{~h}$ to yield 2-amino-6-bromobenzoic acid $(9.18 \mathrm{~g})$ as a brown solid. ${ }^{1} \mathrm{H}$ NMR $\left(400 \mathrm{MHz}, \mathrm{DMSO}-\mathrm{d}_{6}\right) \delta$ ppm $6.72(1 \mathrm{H}, \mathrm{t}, J=7.91 \mathrm{~Hz}), 6.60(1 \mathrm{H}, \mathrm{dd}, J=7.78,1.00 \mathrm{~Hz}), 6.52(1 \mathrm{H}, \mathrm{dd}, J=7.91,1.13 \mathrm{~Hz})$. LCMS [M+1] 200.0.

2-Amino-6-bromobenzoic acid $(2.97 \mathrm{~g}, 13.7 \mathrm{mmol})$ was suspended in a mixture of water $(100 \mathrm{~mL})$ and acetic acid $(1.5 \mathrm{~mL})$ at $35^{\circ} \mathrm{C}$ then a suspension of sodium cyanate $(2.23 \mathrm{~g}, 34.4 \mathrm{mmol})$ in $10 \mathrm{~mL}$ of water was added slowly to the mixture. Upon completion of addition, the resulting mixture was stirred at $35^{\circ} \mathrm{C}$ for 30 minutes and then sodium hydroxide $(24.7 \mathrm{~g}, 619 \mathrm{mmol})$ pellets were slowly added to yield a thick precipitate. The mixture was cooled to $5{ }^{\circ} \mathrm{C}$ in an ice bath and the $\mathrm{pH}$ of the suspension was adjusted to 4 using concentrated $\mathrm{HCl}$. The suspension was filtered and the solid was washed with water and dried under vacuum while heating at $100{ }^{\circ} \mathrm{C}$ to give 5-bromo-1H-quinazoline-2,4-dione (1.91 g) as a brown solid. ${ }^{1} \mathrm{H}$ NMR (400 MHz, DMSO-d 6 ) $\delta$ ppm 11.30 (1 H, br. s.), 11.26 (1 H, br. s.), $7.43-7.48(1 \mathrm{H}, \mathrm{m}), 7.40$ (1 H, dd, J=7.78, $1.25 \mathrm{~Hz}), 7.16(1 \mathrm{H}, \mathrm{dd}, \mathrm{J}=7.91,1.13 \mathrm{~Hz})$.

To a mixture of 5-bromoquinazoline-2,4(1H,3H)-dione (900 mg, $3.73 \mathrm{mmol})$ and $\mathrm{Pd}\left(\mathrm{Ph}_{3} \mathrm{P}\right)_{4}(216 \mathrm{mg}, 0.187 \mathrm{mmol})$ in DME $(90 \mathrm{~mL})$ was added phenylboronic acid $(683 \mathrm{mg}, 5.60 \mathrm{mmol}$ ) followed by a solution of sodium carbonate $(941 \mathrm{mg}, 11.2 \mathrm{mmol})$ in water $(30 \mathrm{~mL})$ and the reaction heated at reflux for $40 \mathrm{~h}$. On cooling to RT, the organic solvent was removed under reduced pressure. The resulting mixture was filtered and the solid washed with water. The solid was concentrated under reduced pressure from $\mathrm{MeOH} / \mathrm{DCM}$ to yield 5-phenylquinazoline2,4 $(1 \mathrm{H}, 3 \mathrm{H})$-dione as an off-white solid. 5-phenylquinazoline-2,4 $(1 \mathrm{H}, 3 \mathrm{H})$-dione $(9.64 \mathrm{~g}, 40.4 \mathrm{mmol})$ was added to $\mathrm{POCl}_{3}(75 \mathrm{~mL}, 810 \mathrm{mmol})$ followed by $\mathrm{PhN}\left(\mathrm{CH}_{3}\right)_{2}(10.3 \mathrm{~mL}, 81.0 \mathrm{mmol})$. Upon completion of addition, the reaction mixture was heated to reflux $\left(105^{\circ} \mathrm{C}\right)$ for 2 hours. The reaction mixture was allowed to cool to ambient temperature and concentrated under reduced pressure, diluted with DCM and then quenched by the addition of cold $1 \mathrm{M} \mathrm{K}_{3} \mathrm{PO}_{4}$ solution. The organic layer was separated and the aqueous layer was extracted twice with DCM. The combined organic layers were dried over $\mathrm{MgSO}_{4}$, filtered and concentrated under reduced pressure to yield a residue which was purified by ISCO chromatography (330 g column) using hexanes/EtOAc (0-25\%) to give 2,4dichloro-5-phenylquinazoline (7.11 g, $63.9 \%$ yield) as a yellow solid. ${ }^{1} \mathrm{H}$ NMR (400 MHz, chloroform-d) ppm 8.04 $(1 \mathrm{H}, \mathrm{m}) 7.96(1 \mathrm{H}, \mathrm{m}) 7.59(1 \mathrm{H}, \mathrm{dd}, \mathrm{J}=7.28,1.25 \mathrm{~Hz}) 7.45(3 \mathrm{H}, \mathrm{dd}, \mathrm{J}=5.02,1.76 \mathrm{~Hz}) 7.32(2 \mathrm{H}, \mathrm{m})$.

2,4-Dichloro-5-phenylquinazoline (1.38 g, $5.03 \mathrm{mmol})$ was dissolved in THF $(80 \mathrm{~mL})$ and triethylamine $(1.33 \mathrm{~mL}$, $9.56 \mathrm{mmol}$ ) was added dropwise. The mixture was stirred for $5 \mathrm{~min}$ at room temperature and then pyridin-2- 
ylmethanamine $(0.57 \mathrm{~mL}, 5.53 \mathrm{mmol})$ was added dropwise. The resulting mixture was stirred at ambient temperature for 14 hours then filtered through a medium porosity glass frit, concentrated to dryness under reduced pressure and then purified by ISCO flash column chromatography ( $80 \mathrm{~g}$ silica gel column) eluting with 0$100 \%$ ethyl acetate/hexanes over $30 \mathrm{~min}$ to provide 2-chloro-5-phenyl-N-(pyridin-2-ylmethyl)quinazolin-4-amine (6a) (1.32 g, $75 \%)$. LCMS [M+1] observed 347.1. HPLC Method 6: Purity 99.1\% retention time $6.66 \mathrm{~min} .{ }^{1} \mathrm{H}$ NMR (400 MHz, chloroform-d) $\delta$ ppm $8.16(1 \mathrm{H}, \mathrm{d}, J=4.77 \mathrm{~Hz}), 7.79(1 \mathrm{H}, \mathrm{d}, \mathrm{J}=7.28 \mathrm{~Hz}), 7.70(1 \mathrm{H}, \mathrm{t}, \mathrm{J}=7.78 \mathrm{~Hz})$, $7.59(1 \mathrm{H}, \mathrm{dt}, J=7.53,1.51 \mathrm{~Hz}), 7.40-7.55(5 \mathrm{H}, \mathrm{m}), 7.08-7.25(4 \mathrm{H}, \mathrm{m}), 4.66(2 \mathrm{H}, \mathrm{d}, \mathrm{J}=4.02 \mathrm{~Hz}) .{ }^{13} \mathrm{C} \mathrm{NMR}(100$ MHz, DMSO-d) $\delta$ ppm 160.18, 156.32, 154.19, 151.48, 147.82, 139.21, 139.18, 136.90, 132.62, 129.40, 129.12 (2C), 129.05, 128.94, 128.50, 126.58, 122.27, 121.76, 111.09, 45.92. HRMS 346.09851 (calc), HRMS [M+1] (obs) 347.10617

\section{Compound 6b:}<smiles>Clc1nc(NCc2ccccn2)c2cc(-c3ccccc3)ccc2n1</smiles>

6b

Following the procedure described for $\mathbf{6 a}$, but utilizing 5-bromoindoline-2,3-dione starting material, $\mathbf{6 b}$ was prepared in an overall yield of $27 \%$ (115mg). ${ }^{1} \mathrm{H} \mathrm{NMR}(400 \mathrm{MHz}, D M S O-d 6) \delta \mathrm{ppm} 9.53(1 \mathrm{H}, \mathrm{t}, \mathrm{J}=6.00 \mathrm{~Hz}), 8.72$ $(1 \mathrm{H}, \mathrm{s}), 8.53(1 \mathrm{H}, \mathrm{d}, J=0.80 \mathrm{~Hz}), 8.18(1 \mathrm{H}, \mathrm{dd}, J=0.80,8.00 \mathrm{~Hz}), 7.85(2 \mathrm{H}, \mathrm{t}, J=7.20 \mathrm{~Hz}), 7.71-7.78(2 \mathrm{H}, \mathrm{m})$, 7.27-7.55 $(5 \mathrm{H}, \mathrm{m}), 4.87(2 \mathrm{H}, \mathrm{d}, J=6.00 \mathrm{~Hz})$. LCMS [M+1] = 347.2, HPLC Method 1: retention time $8.12 \mathrm{~min}$, Purity $99.14 \%$, HPLC Method 3: retention time $8.71 \mathrm{~min}$, Purity $99.30 \% .{ }^{13} \mathrm{C} \mathrm{NMR}(100 \mathrm{MHz}$, DMSO-d) $\delta \mathrm{ppm}$ 161.36, 157.71, 156.81, 149.74, 149.06, 138.71, 137.83, 136.82, 132.27, 129.03 (2C), 127.98, 127.25, 126.89 (2C), 122.36, 121.42, 120.74, 113.86, 45.86. HRMS 346.09851 (calc), HRMS [M+1] (obs) 347.10617

\section{Compound 6c:}<smiles>Clc1nc(NCc2ccccn2)c2ccc(-c3ccccc3)cc2n1</smiles>

6c

Following the procedure described for 6a, but utilizing 6-bromoindoline-2,3-dione starting material (2 g, 8.84 $\mathrm{mmol}), 6 \mathrm{c}$ was prepared in an overall yield of $17 \%(405 \mathrm{mg}) .{ }^{1} \mathrm{H} \mathrm{NMR}(400 \mathrm{MHz}, D M S O-d 6) \delta \mathrm{ppm} 9.43(1 \mathrm{H}, \mathrm{t}, J=$ $6.00 \mathrm{~Hz}), 8.53(1 \mathrm{H}, \mathrm{d}, J=4.80 \mathrm{~Hz}), 8.43(1 \mathrm{H}, \mathrm{d}, J=8.80 \mathrm{~Hz}), 7.73-7.94(5 \mathrm{H}, \mathrm{m}), 7.37-7.55(4 \mathrm{H}, \mathrm{m}), 7.29(1 \mathrm{H}, \mathrm{dd}, J$ $=12.40 \mathrm{~Hz}), 4.86(2 \mathrm{H}, \mathrm{d}, J=5.60 \mathrm{~Hz}) \cdot \mathrm{LCMS}[\mathrm{M}+1]=347.2$, HPLC Method 1: retention time 7.49 min, Purity 99.50 \%, HPLC Method 3: retention time 8.77 min, Purity $99.78 \%{ }^{13} \mathrm{C}$ NMR (100 MHz, DMSO-d) $\delta$ ppm 161.14, 157.72, $157.27,150.94,149.04,145.17,138.48,136.79,129.14$ (2C), 128.63, 127.23 (2C), 125.13, 123.91, 123.80, 122.31, 121.28, 112.58, 45.79. HRMS 346.09851 (calc), HRMS [M+1] (obs) 347.10605

\section{Compound 6d:}


<smiles>Clc1nc(NCc2ccccn2)c2cccc(-c3ccccc3)c2n1</smiles>

Following the procedure described for 6a, but utilizing 7-bromoindoline-2,3-dione starting material ( $2 \mathrm{~g}, 8.84$ mmol), $6 \mathrm{c}$ was prepared in an overall yield of $11 \%$ (325mg). ${ }^{1} \mathrm{H} \mathrm{NMR}(400 \mathrm{MHz}, C D C / 3) \delta \mathrm{ppm} 8.64(1 \mathrm{H}, \mathrm{d}, J=$ 4.80 Hz), 8.33-8.34 (1 H, m), 7.98-8.05 (2 H, m), 7.80-7.82 (1 H, m), 7.66-7.70 (3 H, m), 7.27-7.60 (5 H, m), $5.06(2$ $\mathrm{H}, \mathrm{d}, J=4.80 \mathrm{~Hz}$ ).LCMS $[\mathrm{M}+1]=347.2$, HPLC Method 1: retention time $13.30 \mathrm{~min}$, Purity $99.62 \%$, HPLC Method 3: retention time $9.279 \mathrm{~min}$, Purity $99.41 \% .{ }^{13} \mathrm{C}$ NMR (100 MHz, DMSO-d) $\delta$ ppm 161.61, 157.73, 156.69, $149.03,147.79,138.15,138.06,136.78,134.18,130.29$ (2C), 127.81 (2C), 127.258, 125.96, 122.50, 122.30, 121.27, 113.98, 45.84. HRMS 346.09851 (calc), HRMS [M+1] (obs) 347.10614

\section{Compound 7:}<smiles>CN(C)c1nc(NCc2ccccn2)c2c(-c3ccccc3)cccc2n1</smiles>

To a microwave vial charged with 2-chloro-5-phenyl-N-(pyridin-2-ylmethyl)quinazolin-4-amine 6a (25 mg, 0.072 mmol) was added a $2 \mathrm{M}$ solution of dimethylamine in $\mathrm{MeOH}(0.5 \mathrm{~mL}, 1 \mathrm{mmol})$ and the reaction was heated under microwave irradiation at $150^{\circ} \mathrm{C}$ for $15 \mathrm{~min}$. The solvent was removed under vacuum and the residue dissolved in $\mathrm{H} 2 \mathrm{O}$ and extracted with EtOAc (3x). The combined organic extracts were dried $\left(\mathrm{Na}_{2} \mathrm{SO}_{4}\right)$ filtered and concentrated under reduced pressure to give N2,N2-dimethyl-5-phenyl-N4-(pyridin-2-ylmethyl)quinazoline-2,4diamine (26 mg, $0.073 \mathrm{mmol}, 101 \%$ yield) as white solid. ${ }^{1} \mathrm{H}$ NMR $(400 \mathrm{MHz}, \mathrm{CDCl}) \delta \mathrm{ppm} 8.29(1 \mathrm{H}, \mathrm{d}, J=4.84$ $\mathrm{Hz}), 7.53(1 \mathrm{H}, \mathrm{m}), 7.45-7.50(4 \mathrm{H}, \mathrm{m}), 7.41(4 \mathrm{H}, \mathrm{s}), 7.80(1 \mathrm{H}, \mathrm{dd}, J=6.50 \mathrm{~Hz}$ and $J=6.50 \mathrm{~Hz}), 7.02(1 \mathrm{H}, \mathrm{d}, J=6.48$ $\mathrm{Hz}), 6.02(1 \mathrm{br} \mathrm{s}), 4.59(2 \mathrm{H}, \mathrm{d}, J=4.80 \mathrm{~Hz})$. LCMS [M+1] = 356.1, HPLC Method 2: retention time 5.54 min, Purity 95.7\%, HPLC Method 3: retention time $6.40 \mathrm{~min}$, Purity 97.5 \%. ${ }^{13} \mathrm{C}$ NMR (100 MHz, THF-d) $\delta$ ppm 159.53, $156.90,148.31,138.98,135.79,130.28,129.17$ (2C), 128.51 (2C), 127.51, 125.65, 123.19, 121.32, 120.91, $108.18,46.30,35.96$.

\section{Compound 8:}<smiles>N#Cc1nc(NCc2ccccn2)c2c(-c3ccccc3)cccc2n1</smiles>

Dicyanozinc (6.8 mg, $0.058 \mathrm{mmol})$, zinc $(0.377 \mathrm{mg}, 5.77 \mu \mathrm{mol})$, tris(dibenzylideneacetone)dipalladium (0) (5.28 $\mathrm{mg}, 5.77 \mu \mathrm{mol}), 1,1^{\prime}$-bis(diphenylphosphino)ferrocene $(4.80 \mathrm{mg}, 8.65 \mu \mathrm{mol}$ ) were added to a microwave vial containing a solution of $6 a(20 \mathrm{mg}, 0.058 \mathrm{mmol})$ in DMA $(1 \mathrm{~mL})$. The sealed vial under argon was heated to $150{ }^{\circ} \mathrm{C}$ under microwave irradiation for $30 \mathrm{~min}$ then stirred at RT for $24 \mathrm{~h}$. Additional dicyanozinc $(6.77 \mathrm{mg}, 0.058$ 
mmol), zinc (0.377 mg, $5.77 \mu \mathrm{mol})$, tris(dibenzylideneacetone)dipalladium (0) (5.28 mg, $5.77 \mu \mathrm{mol}), 1,1^{\prime}-$ bis(diphenylphosphino)ferrocene $(4.80 \mathrm{mg}, 8.65 \mu \mathrm{mol})$ were added. The sealed vial under argon was heated to $150{ }^{\circ} \mathrm{C}$ under microwave irradiation for $30 \mathrm{~min}$. The reaction mixture was diluted with EtOAc, washed with $10 \%$ $\mathrm{LiCl}$, dried over $\mathrm{MgSO}_{4}$, filtered and concentrated under reduced pressure. The residue was purified by PrepHPLC (YMC Sunfire $5 \mu$ (C18) $30 \times 100$ mm, 20-100\%MeOH (90\% in H2O, 0.1\% TFA) gradient over 14 min with flow rate $40 \mathrm{~mL} / \mathrm{min}$ and UV detection at $220 \mathrm{~nm}$ ). Compound 8 eluted at a retention time of $9.501 \mathrm{~min}$. The fraction was collected and concentrated to a white solid (4 mg, 21\% yield).LCMS [M+1] 338.1, HPLC Method 1, retention time $6.98 \mathrm{~min}$, purity 96\%. $1 \mathrm{H}$ NMR (400 MHz, CHLOROFORM-d) $\delta \mathrm{ppm} 8.16(1 \mathrm{H}, \mathrm{d}, \mathrm{J}=5.02 \mathrm{~Hz}) 7.90(1$ $\mathrm{H}, \mathrm{dd}, J=8.28,1.26 \mathrm{~Hz}) 7.78(1 \mathrm{H}, \mathrm{m}) 7.60(1 \mathrm{H}, \mathrm{td}, J=7.65,1.76 \mathrm{~Hz}) 7.52(3 \mathrm{H}, \mathrm{m}) 7.42(2 \mathrm{H}, \mathrm{m}) 7.37(1 \mathrm{H}$, dd, $J=7.15,1.38 \mathrm{~Hz}) 7.20(1 \mathrm{H}, \mathrm{s}) 7.13(2 \mathrm{H}, \mathrm{m}) 4.64(2 \mathrm{H}, \mathrm{d}, J=4.02 \mathrm{~Hz}) .{ }^{13} \mathrm{C}$ NMR $(100 \mathrm{MHz}, \mathrm{THF}-\mathrm{d}) \delta \mathrm{ppm} 159.32$, $154.80,150.42$, 148.06, 141.18, 139.94, 139.51, 136.26, 132.04, 131.07, 129.22 (2C), 129.05 (2C), 128.34, $128.25,121.74,121.35,116.58,113.09,46.11$. HRMS 337.1328 (calc), HRMS [M+1] (obs) 338.1401

\section{Compound 9:}<smiles>Cc1nc(NCc2ccccn2)c2c(-c3ccccc3)cccc2n1</smiles>

2-chloro-5-phenyl-N-(pyridin-2-ylmethyl)quinazolin-4-amine, 6a $(38.2 \mathrm{mg}, 0.110 \mathrm{mmol})$ and tetrakis(triphenylphosphine)palladium(0) $(13 \mathrm{mg}, 0.011 \mathrm{mmol}$ ) were combined in a $0.2-2 \mathrm{~mL}$ microwave tube which was sealed, evacuated and backfilled with argon. Dry THF $(2 \mathrm{~mL})$ was added and the mixture was stirred to give a yellow solution. Trimethyaluminum $(0.110 \mathrm{~mL}, 0.220 \mathrm{mmol})$ was added dropwise (exotherm and gas evolution observed upon addition) and the mixture was stirred at room temperature for $20 \mathrm{~min}$. The reaction mixture was then heated in an oil bath to $50^{\circ} \mathrm{C}$. After $1.5 \mathrm{~h}$, the reaction mixture was heated to $75^{\circ} \mathrm{C}$ for $14 \mathrm{~h}$. The mixture was heated under microwave irradiation for $5 \mathrm{~min}$ at $100^{\circ} \mathrm{C}$ then the reaction mixture was diluted with $\mathrm{MeOH}(1 \mathrm{~mL})$ followed by water $(3 \mathrm{~mL})$. The mixture was transferred to a seperation funnel and diluted with DCM $(30 \mathrm{~mL})$ and water $(20 \mathrm{~mL})$. The organic layer was separated and the aqueous portion extracted $4 x$ with 30 $\mathrm{mL}$ DCM. The combined organic portions were washed with brine, dried over sodium sulfate and concentrated under reduced pressure. The residue was dissolved in $\mathrm{MeOH}(2 \mathrm{~mL}$ ) and was purified by prep HPLC (YMC Sunfire \%u (C18) 30x100 mm, Mobile Phase A: 10\% MeOH - 90\% H2O - 0.1\% TFA, Mobile Phase B: $90 \% \mathrm{MeOH}-10 \%$ H2O - 0.1\% TFA, gradient 20-100\% B over $10 \mathrm{~min}, 100 \%$ B for $2 \mathrm{~min}$. Compound 9 eluted at $5.05 \mathrm{~min}(7.7 \mathrm{mg}$, 21\%). LCMS [M+1=327.1, HPLC Method 1: 96\% purity, Rt=4.70 min, HPLC Method 2, 94\% purity Rt=4.86 min. ${ }^{13} \mathrm{C}$ NMR (100 MHz, DMSO-d) $\delta$ ppm 163.33, 158.96, 155.74, 148.58, 140.57, 139.07, 137.07, 131.93, 129.48 (2C), 129.41 (2C), 128.66, 128.48, 127.24, 122.54, 122.06, 111.09, 46.33, 26.38. HRMS 326.1531(calc), HRMS [M+1] (obs) 327.1607

\section{Compound 10:}<smiles>c1ccc(-c2cccc3nc(C4CC4)nc(NCc4ccccn4)c23)cc1</smiles> 
To a mixture of zinc bromide $(64.9 \mathrm{mg}, 0.288 \mathrm{mmol}$ ) and 1,1'-bis(diphenylphosphino)ferrocenepalladium(II)dichloride dichloromethane complex $(5.89 \mathrm{mg}, 7.21 \mu \mathrm{mol}$ ) was added anhydrous THF $(0.3 \mathrm{~mL})$. Upon completion of addition, the mixture was cooled to $-78^{\circ} \mathrm{C}$. Cyclopropyl magnesium bromide $(0.288 \mathrm{~mL}$, $0.144 \mathrm{mmol}$ ) was added dropwise and the reaction mixture was stirred at $-78{ }^{\circ} \mathrm{C}$ for $15 \mathrm{~min}$. A solution of 2chloro-5-phenyl-N-(pyridin-2-ylmethyl)quinazolin-4-amine $(50 \mathrm{mg}, 0.14 \mathrm{mmol}$ ) in anhydrous THF (1.5 mL) was added. The resulting mixture was stirred at $-78^{\circ} \mathrm{C}$ for $1 \mathrm{~h}$ and then allowed to warm to room temperature and stirred for $18 \mathrm{~h}$. The reaction mixture was diluted with saturated $\mathrm{NH}_{4} \mathrm{Cl}(5 \mathrm{~mL})$ and the aqueous layer extracted with ethyl acetate $(3 \times 20 \mathrm{~mL})$. The organic portions were combined and washed with saturated $\mathrm{NaCl}$, dried over sodium sulfate and concentrated under reduced pressure to yield a residue which was purified by preparative HPLC (YMC Sunfire 5u C18 30x100 mm, Mobile Phase A: 10\% MeOH - 90\% H2O - 0.1\% TFA, Mobile Phase B: 90\% $\mathrm{MeOH}-10 \% \mathrm{H} 2 \mathrm{O}-0.1 \% \mathrm{TFA}, 20-100 \% \mathrm{~B}$ over $10 \mathrm{~min}, 100 \% \mathrm{~B}$ for $2 \mathrm{~min}$ ) to yield Example 10 (4 mg, 7\% yield) as a pale yellow solid. ${ }^{1} \mathrm{H}$ NMR $(400 \mathrm{MHz}$, chloroform-d) ppm $8.27-8.30(1 \mathrm{H}, \mathrm{m}), 7.77(1 \mathrm{H}, \mathrm{dd}, J=8.46,0.88 \mathrm{~Hz})$, $7.63(1 \mathrm{H}, \mathrm{dd}, \mathrm{J}=8.34,7.07 \mathrm{~Hz}), 7.56(1 \mathrm{H}, \mathrm{td}, J=7.71,1.77 \mathrm{~Hz}), 7.41-7.48(5 \mathrm{H}, \mathrm{m}), 7.04-7.15(3 \mathrm{H}, \mathrm{m}), 6.30(1 \mathrm{H}$, br. s.), $4.57(2 \mathrm{H}, \mathrm{d}, \mathrm{J}=4.55 \mathrm{~Hz}), 2.11-2.20(1 \mathrm{H}, \mathrm{m}), 1.10-1.16(2 \mathrm{H}, \mathrm{m}), 0.92-0.98(2 \mathrm{H}, \mathrm{m}) . \quad \mathrm{LCMS}[\mathrm{M}+1]=353$.

\section{Compound 11:}

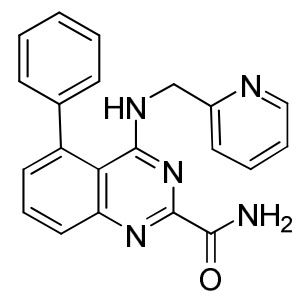

A microwave vial was charged with Compound 8 ( $49 \mathrm{mg}, 0.15 \mathrm{mmol}), \mathrm{KOH}(17 \mathrm{mg}, 0.30 \mathrm{mmol})$, water $(0.5 \mathrm{~mL})$ and THF $(0.5 \mathrm{~mL})$. The sealed vial was heated under microwave irradiation at $100{ }^{\circ} \mathrm{C}$ for $120 \mathrm{~min}$, then at $120^{\circ} \mathrm{C}$ for $30 \mathrm{~min}$. THF was removed under reduced pressure and the residue was taken into DCM, acidified using $1 \mathrm{~N}$ $\mathrm{HCl}$, the organic layer was separated. The aqueous layer was concentrated under reduced pressure and the residue was purified by Prep-HPLC (YMC Sunfire $5 \mu$ (C18) $30 \times 100$ mm, 20-100\%MeOH (90\% in H2O, 0.1\% TFA) using gradient over $12 \mathrm{~min}$ with flow rate $40 \mathrm{~mL} / \mathrm{min}$ and UV detection at $220 \mathrm{~nm}$ ). Compound 11 eluted at retention time of $5.798 \mathrm{~min}$ ( $26 \mathrm{mg}$, 48\% yield). LCMS M/Z-: 354.2, 355.3; $1 \mathrm{H}$ NMR (400 MHz, CHLOROFORM-d) ppm $8.56(1 \mathrm{H}, \mathrm{s}) 8.52(1 \mathrm{H}, \mathrm{d}, \mathrm{J}=5.27 \mathrm{~Hz}) 8.31(1 \mathrm{H}, \mathrm{d}, J=8.28 \mathrm{~Hz}) 8.18(1 \mathrm{H}, \mathrm{t}, J=7.65 \mathrm{~Hz}) 8.02(1 \mathrm{H}, \mathrm{t}, J=7.91 \mathrm{~Hz})$ $7.90(1 \mathrm{H}, \mathrm{t}) 7.82(1 \mathrm{H}, \mathrm{d}, \mathrm{J}=7.78 \mathrm{~Hz}) 7.57(6 \mathrm{H}, \mathrm{m}) 7.45(2 \mathrm{H}, \mathrm{m}) 5.22(2 \mathrm{H}, \mathrm{s})$. HPLC: Method 1, 90\% purity, Rt=4.86 min, HPLC Method 3, purity 90, Rt=5.94 min. ${ }^{13} \mathrm{C}$ NMR (100 MHz, DMSO-d) $\delta$ ppm 160.25, 158.50, 158.50, 154.26 , 149.50, 148.50, 140.05, 138.15, 137.72, 134.91, 132.01, 129.89 (2C), 129.61 (2C), 129.56, 137.50, 123.02, 122.24, 111.37, 47.02. HRMS 355.1433 (calc), HRMS [M+1] (obs) 356.1507

\section{Compound 12:}




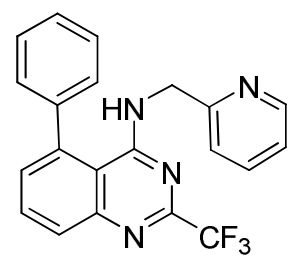

U.S. Patent No. 3,843,791. To a solution of 2-amino-6-chlorobenzoic acid $(1.91 \mathrm{~g}, 11.13 \mathrm{mmol})$ in a mixture of chloroform $(22 \mathrm{~mL})$ and dry pyridine $(1.5 \mathrm{~mL})$ at $0{ }^{\circ} \mathrm{C}$ was added trifluoroacetic anhydride $(3.52 \mathrm{~mL}, 24.9 \mathrm{mmol})$. The reaction mixture was heated to reflux for $2 \mathrm{~h}$ and then allowed to cool to room temperature and concentrated under reduced pressure. The residue was dissolved in chloroform ( $22 \mathrm{~mL})$, saturated with ammonia gas and then stirred for $30 \mathrm{~min}$ at room temperature. The mixture was concentrated under reduced pressure and the resulting solid was washed with $1 \mathrm{~N} \mathrm{HCl}(2 \times 20 \mathrm{~mL})$, diluted with ethyl acetate $(100 \mathrm{~mL})$ and water $(100 \mathrm{~mL})$. The organic layer was separated and the aqueous layer was extracted with ethyl acetate (100 $\mathrm{mL}$ ). The combined organic portions were dried over $\mathrm{MgSO}_{4}$, filtered and concentrated under reduced pressure and the residue purified by flash chromatography on silica gel eluting with 2-15\% ethyl acetate/hexanes to afford 5-chloro-2-(trifluoromethyl)quinazolin-4(3H)-one (1.3 g, 46\%) as a white solid. ${ }^{1} \mathrm{H} \mathrm{NMR}(400 \mathrm{MHz}$, chloroform-d) ppm 10.23 (1 H, br. s.), 7.71 - 7.82 ( $2 \mathrm{H}, \mathrm{m}), 7.64(1 \mathrm{H}, \mathrm{d}, \mathrm{J}=7.15 \mathrm{~Hz})$. LCMS [M+1] = 250 .

Palladium (II) acetate (19 mg, $0.085 \mathrm{mmol}$ ), potassium fluoride (498 mg, $8.57 \mathrm{mmol}), 2$-(di-tertbutylphosphino)biphenyl (51.1 mg, $0.171 \mathrm{mmol}$ ), and phenylboronic acid (522 mg, $4.27 \mathrm{mmol}$ ) were combined in a microwave vial under an argon atmosphere. A solution of 5-chloro-2-(trifluoromethyl)quinazolin-4(3H)-one (710 $\mathrm{mg}, 2.86 \mathrm{mmol})$ in dry THF $(9 \mathrm{~mL})$ was added and the mixture was heated under microwave irradiation at $100^{\circ} \mathrm{C}$ for $30 \mathrm{~min}$. The reaction mixture was diluted with ethyl acetate $(50 \mathrm{~mL})$ and washed with $1 \mathrm{~N} \mathrm{NaOH}(25$ $\mathrm{mL}$ ) and saturated $\mathrm{NaCl}(25 \mathrm{~mL})$. The organic layer was separated, dried over sodium sulfate and concentrated under reduced pressure to give 5-phenyl-2-(trifluoromethyl)quinazolin-4(3H)-one (968 mg), which was used in the next step without further purification.

To 5-phenyl-2-(trifluoromethyl)quinazolin-4(3H)-one (968 mg), was added phosphorous oxychloride (2.86 mL, $307 \mathrm{mmol}$ ) and $\mathrm{N}, \mathrm{N}$-dimethylaniline $(425 \mu \mathrm{L}, 3.34 \mathrm{mmol})$. The reaction mixture was heated to $100^{\circ} \mathrm{C}$ for $10 \mathrm{~min}$. The reaction mixture was allowed to cool to room temperature and the solvents were removed under reduced pressure to yield a residue, which was dissolved in dichloromethane $(20 \mathrm{~mL})$. The dichloromethane solution was added to $50 \mathrm{~mL}$ of a $1.5 \mathrm{M} \mathrm{KH}_{2} \mathrm{PO}_{4}$ solution. The dichloromethane was removed under reduced pressure and the aqueous layer was extracted with DCM $(3 \times 50 \mathrm{~mL})$. The combined organic portions were dried over sodium sulfate and concentrated under reduced pressure to yield a residue which was purified by flash chromatography on silica gel eluting with $100 \%$ DCM to yield 4-chloro-5-phenyl-2-(trifluoromethyl)quinazoline (610 mg, 59\% yield) as a white solid. ${ }^{1} \mathrm{H}$ NMR (400 MHz, chloroform-d) ppm $8.27(1 \mathrm{H}, \mathrm{d}, J=8.53 \mathrm{~Hz}), 8.07(1 \mathrm{H}, \mathrm{t}, \mathrm{J}=7.78 \mathrm{~Hz})$, $7.75(1 \mathrm{H}, \mathrm{d}, \mathrm{J}=7.03 \mathrm{~Hz}), 7.42-7.54(3 \mathrm{H}, \mathrm{m}), 7.29-7.38(2 \mathrm{H}, \mathrm{m})$. LCMS [M+1] = 309.

To a solution of 4-chloro-5-phenyl-2-(trifluoromethyl)quinazoline (200mg, $0.648 \mathrm{mmol}$ ) in THF (15 mL) was added triethylamine $(0.172 \mathrm{~mL}, 1.23 \mathrm{mmol})$. To the reaction mixture was added pyridin-2-ylmethanamine $(0.080 \mathrm{~mL}, 0.78 \mathrm{mmol})$ and the resulting solution was stirred at room temperature for $1 \mathrm{~h}$ and then filtered. The filtrate was concentrated under reduced pressure to yield a residue which was purified by flash chromatography on silica gel eluting with 0-75\% ethyl acetate/hexanes to yield Compound 12 ( $220 \mathrm{mg}, 88 \%$ yield) as a white solid. ${ }^{1} \mathrm{H}$ NMR (400 MHz, chloroform-d) ppm $8.20(1 \mathrm{H}, \mathrm{d}, \mathrm{J}=4.55 \mathrm{~Hz}), 7.99(1 \mathrm{H}, \mathrm{d}, J=8.34 \mathrm{~Hz}), 7.78(1 \mathrm{H}, \mathrm{t}, J=7.71$ $\mathrm{Hz}), 7.59(1 \mathrm{H}, \mathrm{t}, J=7.58 \mathrm{~Hz}), 7.42-7.54(5 \mathrm{H}, \mathrm{m}), 7.35(1 \mathrm{H}, \mathrm{d}, J=7.33 \mathrm{~Hz}), 7.03-7.22(3 \mathrm{H}, \mathrm{m}), 4.69(2 \mathrm{H}, \mathrm{d}, J=4.04$ 
$\mathrm{Hz}$ ). LCMS $[\mathrm{M}+1]=381 . \mathrm{HPLC}$ Method 1, retention time $=5.73 \mathrm{~min}$, purity 96\%, HPLC Method 2, retention time $6.50 \mathrm{~min}$, purity $97 \% .{ }^{13} \mathrm{C} \mathrm{NMR}\left(100 \mathrm{MHz}, \mathrm{CD}_{2} \mathrm{Cl}_{2}\right) \delta \mathrm{ppm} 160.11,154.98,150.20,148.33,139.93,139.22,132.01$, $130.63,129.31(2 \mathrm{C}), 129.06$ (2C), 128.44, 121.95, 121.54, 113.00, 46.38.

\section{Compound 13a:}

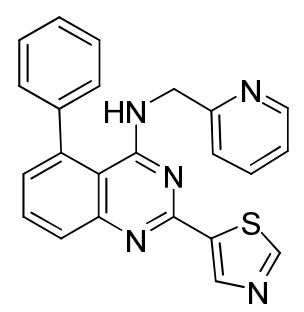

Compound 6a (80 mg, $0.24 \mathrm{mmol}$ ) and bis(triphenylphosphine)palladium(II) chloride $(8.10 \mathrm{mg}, 11.5 \mu \mathrm{mol})$ in DMF were combined in a microwave vial and were degassed with argon for $10 \mathrm{~min}$. 5-tributylstannyl-thiazole (103 $\mathrm{mg}, 0.276 \mathrm{mmol})$ in THF $(0.34 \mathrm{~mL})$ was added under argon and the reaction mixture heated under microwave irradiation at $100^{\circ} \mathrm{C}$ for $60 \mathrm{~min}$. The vial was further heated under microwave irradiation at $120^{\circ} \mathrm{C}$ for $30 \mathrm{~min}$ then concentrated under reduced pressure. The residue was purified by Prep-HPLC (YMC Sunfire $5 \mu$ (C18) $30 \times 100 \mathrm{~mm}, 20-100 \% \mathrm{MeOH}\left(90 \%\right.$ in $\mathrm{H}_{2} \mathrm{O}, 0.1 \%$ TFA) using gradient over 14 min with flow rate $40 \mathrm{~mL} / \mathrm{min}$ and UV detection at $220 \mathrm{~nm}$ ). Compound 13a eluted at a retention time of $8.14 \mathrm{~min}$. The fraction containing product was concentrated under reduced pressure and the residue was diluted with EtOAc, washed with saturated $\mathrm{NaHCO}_{3}$, dried over $\mathrm{MgSO}_{4}$, filtered and concentrated to give a white solid (21 mg, $23 \%$ yield). LCMS M/Z:396.3, 397.4; ${ }^{1} \mathrm{H}$ NMR (400 MHz, CHLOROFORM-D) ppm $8.85(1 \mathrm{H}, \mathrm{s}) 8.73(1 \mathrm{H}, \mathrm{s}) 8.26(1 \mathrm{H}, \mathrm{d}, \mathrm{J}=4.77 \mathrm{~Hz})$ $7.86(1 \mathrm{H}, \mathrm{dd}, J=8.28,1.25 \mathrm{~Hz}) 7.68(1 \mathrm{H}, \mathrm{m}) 7.58(1 \mathrm{H}, \mathrm{td}, J=7.65,1.76 \mathrm{~Hz}) 7.46(5 \mathrm{H}, \mathrm{m}) 7.20(1 \mathrm{H}, \mathrm{dd}, J=7.28,1.25$ $\mathrm{Hz}) 7.15(1 \mathrm{H}, \mathrm{d}, \mathrm{J}=8.03 \mathrm{~Hz}) 7.11(1 \mathrm{H}, \mathrm{dd}, \mathrm{J}=7.03,5.27 \mathrm{~Hz}) 6.64(1 \mathrm{H}, \mathrm{s}) 4.70(2 \mathrm{H}, \mathrm{d}, \mathrm{J}=4.52 \mathrm{~Hz})$. HPLC: Method 1, purity 95\%, Rt=8.25 min, HPLC Method 3, purity 93\%, Rt=9.50 min. ${ }^{13} \mathrm{C} \mathrm{NMR} \mathrm{(100} \mathrm{MHz,} \mathrm{DMSO-d)} \delta$ ppm 159.16, 157.46, 155.85, 155.35, 151.24, 148.69, 144.25, 140.21, 137.17, 136.50, 137.17, 132.63, 129.52 (2C), 129.41 (2C), 128.88, 127.79, 122.62, 122.04, 111.50, 46.43. HRMS 395.1205 (calc) , HRMS [M+1] (obs) 396.1278

\section{Compound 13b:}<smiles>c1ccc(Cc2nc(-c3cncn3-c3ccncc3)nc3cccc(-c4ccccc4)c23)cc1</smiles>

Compound 6a (20 mg, $0.058 \mathrm{mmol}$ ) was coupled with 1-methyl-5-(tributylstannyl)-1H-imidazole (26 mg, 0.069 $\mathrm{mmol})$ in THF $(0.17 \mathrm{~mL})$ under the conditions described for compound 13a. The reaction was concentrated under reduced pressure and purified by Prep-HPLC (YMC Sunfire $5 \mu$ (C18) $30 \times 100 \mathrm{~mm}, 20-100 \% \mathrm{MeOH}(90 \%$ in $\mathrm{H}_{2} \mathrm{O}, 0.1 \%$ TFA) gradient over $16 \mathrm{~min}$ with flow rate $40 \mathrm{~mL} / \mathrm{min}$ and UV detection at $220 \mathrm{~nm}$ ). Compound 13b eluted at a retention time of $7.59 \mathrm{~min}$. and the fraction containing product was concentrated under reduced pressure. The residue was diluted with DCM, washed with saturated $\mathrm{NaHCO}_{3}$, dried over $\mathrm{MgSO}_{4}$, filtered and concentrated to give a white solid (12 mg, $50 \%$ yield). LCMS M/Z: 393.2, 394.2; ${ }^{1} \mathrm{H} \mathrm{NMR} \mathrm{(400} \mathrm{MHz,}$

CHLOROFORM-D) $\delta$ ppm $8.27(1 \mathrm{H}, \mathrm{d}, \mathrm{J}=5.02 \mathrm{~Hz}) 7.92(1 \mathrm{H}, \mathrm{d}, \mathrm{J}=1.00 \mathrm{~Hz}) 7.82(1 \mathrm{H}, \mathrm{dd}, \mathrm{J}=8.53,1.25 \mathrm{~Hz}) 7.67(1 \mathrm{H}$, m) $7.57(1 \mathrm{H}, \mathrm{td}, J=7.65,1.76 \mathrm{~Hz}) 7.52(1 \mathrm{H}, \mathrm{s}) 7.48(5 \mathrm{H}, \mathrm{m}) 7.18(1 \mathrm{H}, \mathrm{dd}, J=7.15,1.38 \mathrm{~Hz}) 7.11(2 \mathrm{H}, \mathrm{m}) 6.48(1 \mathrm{H}$, 
m) $4.67(2 \mathrm{H}, \mathrm{d}, J=4.52 \mathrm{~Hz}) 4.14(3 \mathrm{H}, \mathrm{s})$. HPLC Method 1, purity 90\%, Rt=4.86 min, HPLC Method 2, purity $90 \%$ $\mathrm{Rt}=5.94 \mathrm{~min} .{ }^{13} \mathrm{C}$ NMR $(100 \mathrm{MHz}$, DMSO-d) $\delta \mathrm{ppm} 161.47,161.17,155.15,151.78,148.23,140.93,139.48$, 133.58, 132.50, 131.22, 129.34 (2C), 129.19 (2C), 129.00, 128.29, 127.23, 125.06, 122.63, 110.70, 35.32, 35.26. HRMS 392.1749 (calc), HRMS [M+1] (obs) 393.1810

\section{Compound 13c:}<smiles>Cc1onc(-c2ccnc(CNc3nc(-c4ccccc4)ccc3-c3ccccc3)c2)c1C</smiles>

To a solution of Compound $6 \mathrm{a}(0.200 \mathrm{~g}, 0.57 \mathrm{mmol})$ in 1,4-dioxane $(10 \mathrm{~mL})$ and water $(3 \mathrm{~mL})$ was added $\mathrm{CsCO}_{3}$ (0.376 g, $1.14 \mathrm{mmol})$, followed by 3,5-dimethyl-4-(4,4,5,5-tetramethyl-1,3,2-dioxaborolan-2-yl)isoxazole (0.101 g, $0.570 \mathrm{mmol})$. The reaction mixture degassed for $15 \mathrm{~min}$ with nitrogen and then bis(diphenylphosphino)ferrocene-palladium(II)dichloride $(0.020 \mathrm{~g}, 0.027 \mathrm{mmol})$ was added. The resulting slurry was degassed with nitrogen for $20 \mathrm{~min}$ and then heated to $110^{\circ} \mathrm{C}$ for $14 \mathrm{~h}$. The reaction mixture was diluted with water and the solution extracted with dichloromethane. The combined organic layers were dried over sodium sulfate, filtered and concentrated under reduced pressure. The residue was purified by column chromatography using silica gel and eluting with $2 \%$ Methanol in chloroform to obtain 2-(3,5-dimethylisoxazol4-yl)-5-phenyl- $\mathrm{N}$-(pyridin-2-ylmethyl)quinazolin-4-amine, Compound $13 \mathrm{c}(0.040 \mathrm{~g}, 17 \%)$ as an off white solid. ${ }^{1} \mathrm{H}$ NMR $(400 \mathrm{MHz}, D M S O-d 6) \delta \mathrm{ppm} 8.23(1 \mathrm{H}, \mathrm{d}, J=4.40 \mathrm{~Hz}), 7.69-7.82(3 \mathrm{H}, \mathrm{m}), 7.51-7.57(5 \mathrm{H}, \mathrm{m}), 7.21-7.26(3 \mathrm{H}$, $\mathrm{m}), 6.74(1 \mathrm{H}, \mathrm{t}, J=4.40 \mathrm{~Hz}), 4.63(2 \mathrm{H}, \mathrm{d}, J=4.00 \mathrm{~Hz}), 2.82(3 \mathrm{H}, \mathrm{s}), 2.59(3 \mathrm{H}, \mathrm{s}) . \mathrm{LCMS}[\mathrm{M}+1]=408.2$, HPLC Method 1 : retention time $8.73 \mathrm{~min}$, Purity $97 \%$, HPLC Method 4: retention time 13.34 min, Purity 98\%. ${ }^{13} \mathrm{C}$ NMR $(100$ MHz, DMSO-d) $\delta$ ppm 171.12, 159.93, 159.06, 156.17, 155.85, 151.21, 148.68, 140.42, 139.18, 137.14, 132.28, 129.53 (2C), 129.46 (2C), 128.99, 128.79, 127.94, 122.59, 121.83, 114.37, 111.16, 46.70, 13.97, 13.13. HRMS 407.1746 (calc), HRMS [M+1] (obs) 408.1811

\section{Compound 13d:}

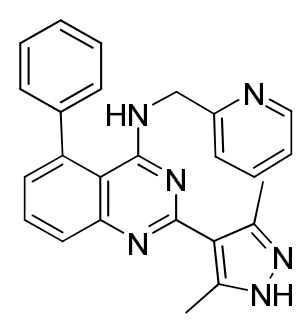

To a solution of Compound $6 \mathrm{a}(0.100 \mathrm{~g}, 0.280 \mathrm{mmol})$ in toluene $(8 \mathrm{~mL})$ and water $(2 \mathrm{~mL})$ was added $\mathrm{Na}_{2} \mathrm{CO}_{3}$ (0.089 mg, $0.84 \mathrm{mmol})$, followed by 3,5-dimethyl-4-(4,4,5,5-tetramethyl-1,3,2-dioxaborolan-2-yl)-1H-pyrazole $(0.096 \mathrm{~g}, 0.43 \mathrm{mmol})$. The reaction mixture was degassed for $30 \mathrm{~min}$ with nitrogen and then tetrakis (triphenylphosphine)palladium $(0.0190 \mathrm{~g}, 0.0160 \mathrm{mmol}$ ) was added. The resulting slurry was degassed with nitrogen for $15 \mathrm{~min}$ and then heated to $110^{\circ} \mathrm{C}$ for $14 \mathrm{~h}$. The reaction mixture was filtered through a celite bed and washed with water then extracted with EtOAc $(3 \times 50 \mathrm{~mL})$. The combined organic layers were washed with water, dried over sodium sulfate, filtered and concentrated under reduced pressure. The residue was purified by 
column chromatography using silica gel (60-120 mesh) and eluting with $0.3 \% \mathrm{MeOH}$ in chloroform to obtain Compound 13d (0.050 g, $43 \%$ ) as an off white solid. ${ }^{1} \mathrm{H}$ NMR (400 MHz, DMSO-d6) $\delta \mathrm{ppm} 12.38(1 \mathrm{H}, \mathrm{s}), 8.23(1$ $\mathrm{H}, \mathrm{d}, J=4.40 \mathrm{~Hz}), 7.67-7.73(3 \mathrm{H}, \mathrm{m}), 7.47-7.51(5 \mathrm{H}, \mathrm{m}), 7.13-7.22(3 \mathrm{H}, \mathrm{m}), 6.48(1 \mathrm{H}, \mathrm{t}, J=4.40 \mathrm{~Hz}), 4.60(2 \mathrm{H}, \mathrm{d}$, $J=4.40 \mathrm{~Hz}), 2.59(3 \mathrm{H}, \mathrm{s}), 2.52(3 \mathrm{H}, \mathrm{s}) . \mathrm{LCMS}[\mathrm{M}+1]=407.2$, HPLC Method 1: retention time 6.04 min, Purity 94 \%, HPLC Method 3: retention time $7.31 \mathrm{~min}$, Purity 94\%. ${ }^{13} \mathrm{C}$ NMR (100 MHz, DMSO-d) $\delta$ ppm 158.83, 156.21, $148.72,140.70,139.08,137.09,131.94,129.51$ (2C), 129.39 (2C), 129.28, 128.68, 127.95, 122.52, 121.74, 119.41, 46.76, 25.41, 14.35. HRMS 406.1906 (calc), HRMS [M+1] (obs) 407.1970

\section{Compound 13e:}

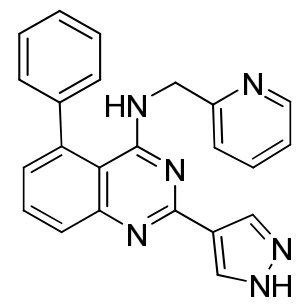

To a solution of Compound $6 \mathrm{a}(0.30 \mathrm{~g}, 0.86 \mathrm{mmol})$ in DMF $(5 \mathrm{~mL})$ and water $(2 \mathrm{~mL})$ was added $\mathrm{K}_{2} \mathrm{CO}_{3}(0.237 \mathrm{~g}$, $1.71 \mathrm{mmol})$, followed by 2 4-(4,4,5,5-tetramethyl-1,3,2-dioxaborolan-2-yl)-1H-pyrazole (0.251 g, $1.29 \mathrm{mmol})$. The reaction mixture was degassed for $30 \mathrm{~min}$ with nitrogen and then tetrakis(triphenylphosphine) palladium $(0.0100 \mathrm{~g}, 0.00800 \mathrm{mmol})$ was added. The resulting slurry was degassed with nitrogen for $15 \mathrm{~min}$ and then heated to $110{ }^{\circ} \mathrm{C}$ for $14 \mathrm{~h}$. The reaction mixture was diluted with water and was then extracted with EtOAc ( $3 \times 50$ $\mathrm{mL}$ ). The combined organic layers were washed with water and dried over sodium sulfate, filtered and concentrated under reduced pressure. The residue was purified by column chromatography using silica gel (230400 mesh) and eluting with 20-40 \% EtOAc in hexane to obtain Compound 13 e $(0.20 \mathrm{~g}, 61 \%)$ as an off white solid. ${ }^{1} \mathrm{H}$ NMR (400 MHz, DMSO-d6) $\delta$ ppm $13.10(1 \mathrm{H}, \mathrm{s}), 8.35(1 \mathrm{H}, \mathrm{s}), 8.24(1 \mathrm{H}, \mathrm{s}), 8.23(1 \mathrm{H}, \mathrm{s}), 7.69-7.71(3 \mathrm{H}$, m), 7.47-7.53 (5 H, m), 7.15-7.29 (3 H, m), $6.58(1 \mathrm{H}, \mathrm{s}), 4.66(2 \mathrm{H}, \mathrm{dd}, J=4.00, \mathrm{~Hz}) . \mathrm{LCMS}[\mathrm{M}+1]=379.2, \mathrm{HPLC}$ Method 1: retention time $6.44 \mathrm{~min}$, Purity 94\%, HPLC Method 3: retention time $7.43 \mathrm{~min}$, Purity $94 \%{ }^{13} \mathrm{C}$ NMR (100 MHz, DMSO-d) $\delta$ ppm 159.10, 156.99, 156.39, 148.71, 140.67, 139.18, 137.07, 132.02, 129.51 (2C), 129.41 (2C), 128.69, 128.12, 127.51, 126.98, 123.04, 122.51, 121.98, 111.50, 46.40. HRMS 378.1593 (calc), HRMS [M+1] (obs) 379.1657

\section{Compound 13f:}<smiles>c1ccc(-c2cccc3nc(-c4ccccn4)nc(NCc4ccccn4)c23)cc1</smiles>

Compound 6a (47.7 mg, $0.138 \mathrm{mmol})$, pyridin-3-ylboronic acid $(25.4 \mathrm{mg}, 0.206 \mathrm{mmol})$, bis(triphenylphosphine)palladium(II) chloride ( $4.83 \mathrm{mg}, 6.88 \mu \mathrm{mol}), \mathrm{K}_{2} \mathrm{CO}_{3}(95 \mathrm{mg}, 0.69 \mathrm{mmol}$ ) were combined in a $2 \mathrm{~mL}$ microwave tube which was sealed and evacuated. The tube was backfilled with argon and the solvent mixture, which had been degassed by bubbling argon for $10 \mathrm{~min}$, was added. The tube was resealed and heated under microwave irradiation for $10 \mathrm{~min}$ at $100^{\circ} \mathrm{C}$. The reaction mixture was diluted with ethyl acetate $(30 \mathrm{~mL})$ 
and washed with water $(20 \mathrm{~mL})$, followed by brine $(20 \mathrm{~mL})$. The organic portion was dried over sodium sulfate and concentrated under reduced pressure. The residue was dissolved in DCM and purified by ISCO (12g) eluting with $0-3 \% \mathrm{MeOH} / \mathrm{DCM}$ over $12 \mathrm{~min}$ followed by $3-5 \%$ over $5 \mathrm{~min}$ and $5 \%$ for $10 \mathrm{~min}$. Compound $13 \mathrm{f} 34 \mathrm{mg}$ (63\% yield) was obtained as an off white solid. LCMS $[M+1]=390.3, \mathrm{Rt}=0.72 \mathrm{~min}$, HPLC: Method 1, 97.8\% purity, retention time $4.90 \mathrm{~min}{ }^{13} \mathrm{C}$ NMR $(100 \mathrm{MHz}$, DMSO-d) $\delta \mathrm{ppm} 159.32,157.76,155.93,151.43,151.35,149.79$, $148.61,140.35,139.30,137.12,135.59,133.93,132.40,129.55$ (2C), 129.49 (2C), 129.44, 128.81, 128.33, 123.93, 122.56, 122.01, 111.98, 46.47. HRMS 389.1641 (calc), HRMS [M+1] (obs) 390.1707

\section{Compound 13g:}<smiles>COc1cncc(-c2nc(NCc3ccccn3)c3c(-c4ccccc4)cccc3n2)c1</smiles>

To a solution of Compound $6 \mathrm{a}(0.100 \mathrm{~g}, 0.285 \mathrm{mmol})$ in DMF $(30 \mathrm{~mL})$ and water $(3 \mathrm{~mL})$ was added $\mathrm{K}_{2} \mathrm{CO}_{3}(0.079$ $\mathrm{g}, 0.57 \mathrm{mmol})$, followed by 4-(4,4,5,5-tetramethyl-1,3,2-dioxaborolan-2-yl)pyridine (0.101 g, $0.570 \mathrm{mmol})$. The reaction mixture degassed for $5 \mathrm{~min}$ with nitrogen and then tetrakis(triphenylphosphine)palladium (0.033 $\mathrm{g}$, $0.028 \mathrm{mmol}$ ) was added. The resulting slurry was degassed with nitrogen for $5 \mathrm{~min}$ and then heated to $110^{\circ} \mathrm{C}$ for $2 \mathrm{~h}$. The reaction mixture was diluted with water and was then extracted with dichloromethane. The combined organic layers were dried over sodium sulfate, filtered and concentrated under reduced pressure. The residue was purified by column chromatography using silica gel and eluting with $5 \%$ methanol in chloroform to obtain Compound $13 \mathrm{~g}(0.050 \mathrm{~g}, 41 \%)$ as an off white solid. ${ }^{1} \mathrm{H}$ NMR (400 MHz, DMSO-d6) $\delta \mathrm{ppm} 9.39(1 \mathrm{H}, \mathrm{s}), 8.78(1 \mathrm{H}$, s), $8.49(2 \mathrm{H}, \mathrm{s}), 8.22(1 \mathrm{H}, \mathrm{d}, J=5.60 \mathrm{~Hz}), 7.80(1 \mathrm{H}, \mathrm{t}, J=7.60 \mathrm{~Hz}), 7.48-7.70(7 \mathrm{H}, \mathrm{m}), 7.13-7.34(3 \mathrm{H}, \mathrm{m}), 4.81(2 \mathrm{H}, \mathrm{d}$, $J=4.00 \mathrm{~Hz}), 4.07(3 \mathrm{H}, \mathrm{s})$. LCMS $[\mathrm{M}+1]=420.2$, HPLC Method 3: retention time 9.64 min, Purity $97.6 \%, \mathrm{HPLC}$ Method 1: retention time $8.15 \mathrm{~min}$, Purity $97.8 \%{ }^{13} \mathrm{C}$ NMR (100 MHz, DMSO-d) $\delta$ ppm 159.29, 157.60, 156.07, $155.84,151.36,148.65,142.12,140.31,139.29,137.12,134.79,132.45,129.55$ (2C), 129.51 (2C), 128.85, $128.32,122.56,121.98,119.36,111.98,56.09,46.52$. HRMS 419.1746 (calc), HRMS [M+1] (obs) 420.1815

\section{Compound 13h:}<smiles>c1ccc(-c2cccc3nc(-c4ccncc4)nc(NCc4ccccn4)c23)cc1</smiles>

To a solution of Compound $6 \mathrm{a}(0.100 \mathrm{~g}, 0.285 \mathrm{mmol})$ in DMF $(30 \mathrm{~mL})$ and water $(3 \mathrm{~mL})$ was added $\mathrm{K}_{2} \mathrm{CO}_{3}(0.080$ g, $0.57 \mathrm{mmol})$, followed by 4-(4,4,5,5-tetramethyl-1,3,2-dioxaborolan-2-yl)pyridine $(0.120 \mathrm{~g}, 0.570 \mathrm{mmol})$. The reaction mixture degassed for $5 \mathrm{~min}$ with nitrogen and then tetrakis(triphenylphosphine)palladium (0.030 $\mathrm{g}$, $0.033 \mathrm{mmol}$ ) was added. The resulting slurry was degassed with nitrogen for $5 \mathrm{~min}$ and then heated to $110{ }^{\circ} \mathrm{C}$ for $2 \mathrm{~h}$. The reaction mixture was diluted with water and was then extracted with dichloromethane. The combined organic layers were dried over sodium sulfate, filtered and concentrated under reduced pressure. The residue 
was purified by column chromatography using silica gel and eluting with $5 \%$ methanol in chloroform to obtain Compound $13 \mathrm{~h}(0.010 \mathrm{~g}, 16 \%)$ as an off white solid. ${ }^{1} \mathrm{H}$ NMR $(400 \mathrm{MHz}, \mathrm{DMSO}-\mathrm{d} 6) \delta \mathrm{ppm} 8.75(2 \mathrm{H}, \mathrm{d}, J=3.20$ $\mathrm{Hz}), 8.37(2 \mathrm{H}, \mathrm{d}, J=6.00 \mathrm{~Hz}), 8.22(2 \mathrm{H}, \mathrm{d}, J=4.80 \mathrm{~Hz}), 7.83-7.92(2 \mathrm{H}, \mathrm{m}), 7.12-7.74(8 \mathrm{H}, \mathrm{m}), 6.91(1 \mathrm{H}, \mathrm{d}, J=4.00$ $\mathrm{Hz}), 4.74(2 \mathrm{H}, \mathrm{d}, J=4.40 \mathrm{~Hz})$.LCMS $[\mathrm{M}+1]=390.2$. HPLC Method 1: retention time $6.42 \mathrm{~min}$, Purity $99.5 \%$ HPLC Method 2: retention time $7.36 \mathrm{~min}$, Purity $99.7 \% .{ }^{13} \mathrm{C}$ NMR (100 MHz, DMSO-d) $\delta$ ppm 159.46, 157.50, 155.82, $151.31,150.57,148.62$ (2C), 145.86, 140.23, 139.30, 137.14, 132.50, 129.90, 129.55 (2C), 129.50 (2C), 128.84, $128.52,122.59,122.30$ (2C), 122.01, 112.20, 46.45. HRMS 389.1641 (calc) , HRMS [M+1] (obs) 390.1710

\section{Compound 13i:}

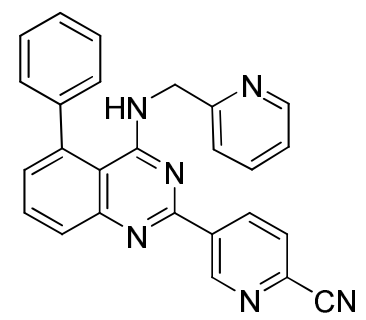

To a solution of Compound $6 \mathrm{a}(0.070 \mathrm{~g}, 0.20 \mathrm{mmol})$ in DMF $(3 \mathrm{~mL})$ was added $\mathrm{K}_{2} \mathrm{CO}_{3}(0.056 \mathrm{~g}, 0.40 \mathrm{mmol})$, followed by 5-(4,4,5,5-tetramethyl-1,3,2-dioxaborolan-2-yl)picolinonitrile $(0.070 \mathrm{~g}, 0.30 \mathrm{mmol})$. The reaction mixture was degassed for $20 \mathrm{~min}$ with nitrogen and then tetrakis(triphenylphosphine)palladium (0.0116 g, 0.01 mmol) was added. The resulting slurry was degassed with nitrogen for $30 \mathrm{~min}$ and then heated to $110^{\circ} \mathrm{C}$ for $2 \mathrm{~h}$. The reaction mixture was diluted with water and was then extracted with ethylacetate $(50 \times 2 \mathrm{~mL})$. The combined organic layers were washed with water and dried over sodium sulfate, filtered and concentrated under reduced pressure. The residue was purified by column chromatography using silica gel (60-120 mesh) and eluting with 20 \% ethylacetate in hexane to obtain Compound $13 \mathrm{i}(0.043 \mathrm{~g}, 52 \%)$ as an off white solid. ${ }^{1} \mathrm{H}$ NMR ( $400 \mathrm{MHz}$, DMSO-d6) $\delta$ ppm $9.85(1 \mathrm{H}, \mathrm{d}, J=1.60 \mathrm{~Hz}), 8.99(1 \mathrm{H}, \mathrm{s}), 8.27(1 \mathrm{H}, \mathrm{d}, J=4.40 \mathrm{~Hz}), 7.76-7.98(1 \mathrm{H}, \mathrm{m}), 7.62(1 \mathrm{H}, \mathrm{t}$, $J=7.60 \mathrm{~Hz}), 7.48-7.53(6 \mathrm{H}, \mathrm{m}), 7.13-7.32(3 \mathrm{H}, \mathrm{m}), 7.01(1 \mathrm{H}, \mathrm{s}), 4.77(2 \mathrm{H}, \mathrm{d}, J=4.00 \mathrm{~Hz}) . \mathrm{LCMS}[\mathrm{M}+1]=415.2$, HPLC Method 1: retention time 16.85 min, Purity 97.3\%, HPLC Method 2: retention time 16.84 min, Purity 97.8 $\%{ }^{13} \mathrm{C}$ NMR $(100 \mathrm{MHz}$, THF-d) $\delta$ ppm 159.39, 156.32, 155.73, 151.53, 150.91, 148.26, 140.61, 139.33, 137.01, $136.16,135.92,134.36,131.43,129.38,129.26$ (2C), 128.91 (2C), 128.42, 128.14, 127.92, 121.66, 121.22, 117.29, 112.20, 100.66, 46.26. HRMS 414.1593 (calc) , HRMS [M+1] (obs) 415.1660

\section{Compound 13j:}<smiles>O=c1ccc(-c2nc(NCc3ccccn3)c3c(-c4ccccc4)cccc3n2)c[nH]1</smiles>

To a solution of Compound $6 \mathrm{a}(0.100 \mathrm{~g}, 0.280 \mathrm{mmol})$ in DMF $(5 \mathrm{~mL})$ and water $(2 \mathrm{~mL})$ was added $\mathrm{K}_{2} \mathrm{CO}_{3}(0.080$ $\mathrm{mg}, 0.57 \mathrm{mmol})$, followed by 2-methoxy-5-(4,4,5,5-tetramethyl-1,3,2-dioxaborolan-2-yl)pyridine (0.101 g, 0.420 $\mathrm{mmol})$. The reaction mixture degassed for $30 \mathrm{~min}$ with nitrogen and then tetrakis (triphenylphosphine) palladium $(0.033 \mathrm{~g}, 0.028 \mathrm{mmol}$ ) was added. The resulting slurry was degassed with nitrogen for $15 \mathrm{~min}$ and then heated to $110^{\circ} \mathrm{C}$ for $2 \mathrm{~h}$. The reaction mixture was diluted with water and was then extracted with EtOAc 
(3x50 mL). The combined organic layers were washed with water and dried over sodium sulfate, filtered and concentrated under reduced pressure. The residue was purified by column chromatography using silica gel (60120 mesh) and eluting with 20-40 \% EtOAc in hexane to obtain 2-(6-methoxypyridin-3-yl)-5-phenyl-N-(pyridin-2ylmethyl)quinazolin-4-amine $(0.10 \mathrm{~g}, 86 \%)$ as a off white solid. ${ }^{1} \mathrm{H}$ NMR $(400 \mathrm{MHz}, D M S O-d 6) \delta \mathrm{ppm} 9.26(1 \mathrm{H}, \mathrm{d}$, $J=2.00 \mathrm{~Hz}), 8.68(1 \mathrm{H}, \mathrm{dd}, J=2.40,8.60 \mathrm{~Hz}),, 8.22(1 \mathrm{H}, \mathrm{d}, J=4.80 \mathrm{~Hz}), 7.69-7.83(3 \mathrm{H}, \mathrm{m}), 7.48-7.56(5 \mathrm{H}, \mathrm{m})$, 7.21-7.32 $(3 \mathrm{H}, \mathrm{m}), 6.94(1 \mathrm{H}, \mathrm{d}, J=8.80 \mathrm{~Hz}), 6.80(1 \mathrm{H}, \mathrm{s}), 4.71(2 \mathrm{H}, \mathrm{d}, J=4.40 \mathrm{~Hz}), 3.94(3 \mathrm{H}, \mathrm{s}) . \mathrm{LCMS}[\mathrm{M}+1]=$ 420.2, HPLC Method 1: retention time 7.60 min, Purity 99.2 \%, HPLC Method 3: retention time 8.93 min, Purity $98.9 \%$.

To a solution of 2-(6-methoxypyridin-3-yl)-5-phenyl-N-(pyridin-2-ylmethyl)quinazolin-4-amine (0.100 g, 0.238 $\mathrm{mmol})$ in DCM $(2 \mathrm{~mL})$ was added borontribromide $(0.417 \mathrm{~g}, 1.67 \mathrm{mmol})$ at ${ }^{0} \mathrm{C}$. The reaction mixture was allowed to stir for $18 \mathrm{~h}$ then concentrated under high vacuum and subjected to preperative HPLC purification to obtain Compound $13 \mathrm{j}$ (0.075 g, 77.3 \%). ${ }^{1} \mathrm{H}$ NMR (400 MHz, DMSO-d6) $\delta \mathrm{ppm} 12.60(1 \mathrm{H}, \mathrm{s}), 8.68(1 \mathrm{H}, \mathrm{s}), 8.40(1 \mathrm{H}, \mathrm{dd}$, $J=2.80,9.60 \mathrm{~Hz}), 8.23(1 \mathrm{H}, \mathrm{d}, J=4.40 \mathrm{~Hz}), 7.79-8.09(4 \mathrm{H}, \mathrm{m}), 7.30-7.65(8 \mathrm{H}, \mathrm{m}), 6.61(1 \mathrm{H}, \mathrm{d}, J=9.60 \mathrm{~Hz}), 4.88$ $(2 \mathrm{H}, \mathrm{d}, J=4.00 \mathrm{~Hz})$. LCMS $[\mathrm{M}+1]=406.2$, HPLC Method 1: retention time $8.54 \mathrm{~min}$, Purity $99.4 \%$, HPLC Method 3: retention time $10.26 \mathrm{~min}$, Purity 99.2 \%. . ${ }^{13} \mathrm{C}$ NMR (100 MHz, DMSO-d) $\delta$ ppm 163.08, 159.40, 159.11, 154.71, 153.82, 147.89, 141.37, 140.26, 139.56, 138.60, 138.02, 135.31, 131.18, 129.93, 129.69 (2C), 129.58 (2C), 123.40, 122.57, 120.17, 119.85, 110.59, 109.77, 46.51. HRMS 405.1590 (calc) , HRMS [M+1] (obs) 406.1654

\section{Compound 13k:}<smiles>c1ccc(-c2cccc3nc(-c4cncnc4)nc(Cc4cccnc4)c23)cc1</smiles>

Compound 6a (225 mg, $0.649 \mathrm{mmol}$ ), pyrimidin-5-ylboronic acid (121 mg, $0.973 \mathrm{mmol}$ ), and bis (triphenylphosphine)palladium (II) chloride $(23 \mathrm{mg}, 0.032 \mathrm{mmol}$ ) were combined in a microwave tube which was sealed, evacuated and then backfilled with argon. Under argon, previously degassed dioxane $(1 \mathrm{~mL})$ and a sodium carbonate $(0.33 \mathrm{~mL}, 0.33 \mathrm{mmol})$ in water $(0.33 \mathrm{~mL})$ solution were added to the reaction mixture. The resulting mixture was heated under microwave irradiation to $100^{\circ} \mathrm{C}$ for $60 \mathrm{~min}$. After this time, additional pyrimidin-5-ylboronic acid (91 mg, $0.78 \mathrm{mmol}$ ) and bis (triphenylphosphine)palladium (II) chloride (17 mg, 0.024 $\mathrm{mmol}$ ) were added and the resulting mixture was heated under microwave irradiation at $100{ }^{\circ} \mathrm{C}$ for 40 min and then allowed to cool to room temperature and stirred for $14 \mathrm{~h}$. The reaction mixture was diluted with $50 \mathrm{~mL}$ of water and ethyl acetate. The organic layer was separated and the aqueous portion was extracted with ethyl acetate. The combined organic portions were washed with $50 \mathrm{~mL}$ of brine, dried over $\mathrm{Na}_{2} \mathrm{SO}_{4}$, decanted and concentrated under reduced pressure to yield a residue which was purified by ISCO ( $40 \mathrm{~g}$ silica gel column) eluting with $0-5 \% \mathrm{MeOH}$ over $15 \mathrm{~min}$ and then $5 \% \mathrm{MeOH}$ for $10 \mathrm{~min}$ to yield Compound 13k (212 mg, 84 \%). ${ }^{1} \mathrm{H}$ NMR $\left(400 \mathrm{MHz}, \mathrm{CDCl}_{3}\right)$ ppm $4.74(\mathrm{~d}, J=4.27 \mathrm{~Hz}, 2 \mathrm{H}) 6.73-6.81(\mathrm{~m}, 1 \mathrm{H}) 7.09-7.16(\mathrm{~m}, 2 \mathrm{H}) 7.25-7.29(\mathrm{~m}, 1 \mathrm{H})$ $7.44-7.52$ (m, 5 H) 7.58 (dt, J=7.72, 1.88 Hz, 1 H) 7.73 (dd, J=8.28, 7.28 Hz, 1 H) 7.93 (dd, J=8.28, 1.25 Hz, 1 H) 8.23 - $8.26(\mathrm{~m}, 1 \mathrm{H}) 9.29(\mathrm{~s}, 1 \mathrm{H}) 9.78(\mathrm{~s}, 2 \mathrm{H})$. LCMS [M+1] = 391; HPLC Method 1: purity 99\%, retention time 5.6 $\min .{ }^{13} \mathrm{C}$ NMR (100 MHz, DMSO-d) $\delta$ ppm 159.78, 159.36, 156.61, 155.92, 155.79, 151.20, 148.58, 140.20, 
$139.40,137.14,132.60,131.65,129.87$ (2C), 129.54 (2C), 128.88, 128.37, 122.58, 122.05, 112.14, 46.50. HRMS

390.1593 (calc), HRMS [M+1] (obs) 391.1652

\section{Compound 13l:}<smiles>COc1ncc(-c2nc(NCc3ccccn3)c3c(-c4ccccc4)cccc3n2)cn1</smiles>

To a solution of Compound $6 \mathrm{a}(0.210 \mathrm{~g}, 0.600 \mathrm{mmol})$ in DMF $(5 \mathrm{~mL})$ and water $(2 \mathrm{~mL})$ was added $\mathrm{K}_{2} \mathrm{CO}_{3}(0.167$ $\mathrm{mg}, 1.21 \mathrm{mmol})$, followed by 2-methoxypyrimidin-5-ylboronic acid $(0.140 \mathrm{~g}, 0.90 \mathrm{mmol})$. The reaction mixture degassed for $30 \mathrm{~min}$ with nitrogen and then tetrakis (triphenylphosphine) palladium $(0.0350 \mathrm{~g}, 0.0300 \mathrm{mmol})$ was added. The resulting slurry was degassed with nitrogen for $15 \mathrm{~min}$ and then heated to $110^{\circ} \mathrm{C}$ for $14 \mathrm{~h}$. The reaction mixture was diluted with water and was then extracted with EtOAc ( $3 \times 50 \mathrm{~mL})$. The combined organic layers were washed with water and dried over sodium sulfate, filtered and concentrated under reduced pressure. The residue was purified by column chromatography using silica gel (60-120 mesh) and eluting the same with 20-30 \% EtOAc in hexane to obtain 2-(6-methoxypyridin-3-yl)-5-phenyl-N-(pyridin-2ylmethyl)quinazolin-4-amine $(0.18 \mathrm{~g}, 71 \%)$ as an off white solid. ${ }^{1} \mathrm{H}$ NMR $(400 \mathrm{MHz}$, DMSO-d6) $\delta \mathrm{ppm} 9.52(2 \mathrm{H}$, s), $8.30(1 \mathrm{H}, \mathrm{d}, J=4.80 \mathrm{~Hz}), 7.94(2 \mathrm{H}, \mathrm{dd}, J=5.60,7.00 \mathrm{~Hz}), 7.87(1 \mathrm{H}, \mathrm{t}, J=7.20 \mathrm{~Hz}), 7.54-7.62(5 \mathrm{H}, \mathrm{m}), 7.34-$ $7.45(4 \mathrm{H}, \mathrm{m}), 4.86(2 \mathrm{H}, \mathrm{d}, J=4.40 \mathrm{~Hz}), 4.06(3 \mathrm{H}, \mathrm{s})$. LCMS [M+1] = 421.2, HPLC Method 1: retention time 8.44 min, Purity $95.8 \%$, HPLC Method 2: retention time $9.40 \mathrm{~min}$, Purity $96.6 \%$. Insufficient solubility for ${ }^{13} \mathrm{C}$ NMR HRMS 420.1698 (calc), HRMS [M+1] (obs) 421.1757

\section{Compound $13 \mathrm{~m}$ :}<smiles>COCCNc1ncc(-c2nc(NCc3ccccn3)c3c(-c4ccccc4)cccc3n2)cn1</smiles>

To a solution of 2-chloropyrimidin-5-ylboronic acid (100 mg, $0.63 \mathrm{mmol})$ in DMF (2 mL) was added 2-methyl ethyl amine $(0.97 \mathrm{~g}, 0.0063 \mathrm{mmol})$ and the reaction mixture heated under microwave irradiation at $150^{\circ} \mathrm{C}$ for 3 h. The volatile components were removed under reduced pressure and the resulting 2-(2methoxyethylamino)pyrimidin-5-ylboronic acid was taken to the next step without any purification.

To a solution of $6 \mathrm{a}(0.100 \mathrm{~g}, 0.289 \mathrm{mmol})$ in DMF $(5 \mathrm{~mL})$ and water $(2 \mathrm{~mL})$ was added $\mathrm{K}_{2} \mathrm{CO}_{3}(0.080 \mathrm{~g}, 0.58 \mathrm{mmol})$, followed by 2-(2-methoxyethylamino)pyrimidin-5-ylboronic acid $(0.01 \mathrm{~g}, 500 \mathrm{mmol})$. The reaction mixture degassed for $30 \mathrm{~min}$ with nitrogen and then tetrakis(triphenylphosphine)palladium $(0.033 \mathrm{~g}, 0.028 \mathrm{mmol})$ was added. The resulting slurry was degassed with nitrogen for $15 \mathrm{~min}$ and then heated to $110{ }^{\circ} \mathrm{C}$ for $14 \mathrm{~h}$. The reaction mixture was diluted with water and extracted with EtOAc ( $50 \times 3 \mathrm{~mL})$. The combined organic layers were washed with water and dried over sodium sulfate, filtered and concentrated under reduced pressure. The 
residue was purified by column chromatography using silica gel (230-400 mesh) eluting with 50-60 \% EtOAc in hexane to obtain 2-(2-(2-methoxyethylamino)pyrimidin-5-yl)-5-phenyl-N-(pyridin-2-ylmethyl)quinazolin-4-amine $(0.028 \mathrm{~g}, 21 \%)$ as an off white solid. ${ }^{1} \mathrm{H}$ NMR $(400 \mathrm{MHz}, \mathrm{DMSO}-\mathrm{d} 6) \mathrm{ppm} 9.26(1 \mathrm{H}, \mathrm{s}), 8.21(1 \mathrm{H}, \mathrm{d}, J=4.80 \mathrm{~Hz})$, 7.65-7.79 $(4 \mathrm{H}, \mathrm{m}), 7.47-7.55(5 \mathrm{H}, \mathrm{m}), 7.18-7.31(3 \mathrm{H}, \mathrm{m}), 6.76(1 \mathrm{H}, \mathrm{d}, J=4.00 \mathrm{~Hz}), 4.68(2 \mathrm{H}, \mathrm{d}, J=4.00 \mathrm{~Hz})$, 3.42-3.53 $(4 \mathrm{H}, \mathrm{m}), 3.30(3 \mathrm{H}, \mathrm{s}) . \mathrm{LCMS}[\mathrm{M}+1]=$ 464.2, HPLC Method 1: retention time 6.86 min, Purity $95.6 \%$, HPLC Method 3: retention time $8.18 \mathrm{~min}$, Purity $94.1 \%$. Insufficient solvent solubility for ${ }^{13} \mathrm{C}$ NMR. HRMS 463.2120 (calc) , HRMS [M+1] (obs) 464.2179

\section{Compound 14a:}<smiles>Fc1ccc(-c2cccc3nc(-c4cncnc4)nc(Cc4cccnc4)c23)cc1</smiles>

To a mixture of 5-bromoquinazoline-2,4(1H,3H)-dione $(1.00 \mathrm{~g}, 4.18 \mathrm{mmol})$ in DME $(15 \mathrm{~mL})$ was added 4fluorophenylboronic acid $(0.87 \mathrm{~g}, 6.2 \mathrm{mmol})$ followed by a solution of sodium carbonate $(1.32 \mathrm{~g}, 12.4 \mathrm{mmol})$ in water $(5 \mathrm{~mL})$ and reaction mixture was purged with nitrogen gas for $15 \mathrm{~min}$. $\mathrm{Pd}(\mathrm{dppf}) \mathrm{Cl}_{2}(0.17 \mathrm{~g}, 0.23 \mathrm{mmol})$ was added to the reaction mixture and nitrogen was passed through the mixture again for $10 \mathrm{~min}$. The reaction mixture was heated at $90{ }^{\circ} \mathrm{C}$ for $48 \mathrm{~h}$. The reaction mixture was allowed to cool and organic solvent was removed under reduced pressure. The resulting mixture was diluted with water and the solids were filtered. The solid was concentrated under reduced pressure from MeOH/DCM to remove the water to yield 5-(4fluorophenyl)quinazoline-2,4(1H,3H)-dione $(1.32 \mathrm{~g}, 123 \%)$ as an off-white solid which was taken to the next step without further purification. LCMS $[\mathrm{M}+1]=257.2$.

The 5-(4-fluorophenyl)quinazoline-2,4(1H,3H)-dione $\left(1.3 \mathrm{~g}, 5.1 \mathrm{mmol}\right.$ ) was added to $\mathrm{POCl}_{3}(60 \mathrm{~mL})$ followed by $\mathrm{PhN}\left(\mathrm{CH}_{3}\right)_{2}(1.1 \mathrm{~mL}, 7.6 \mathrm{mmol})$ at ambient temperature. The reaction mixture was heated to reflux $\left(105^{\circ} \mathrm{C}\right)$ for 12 hours then allowed to cool to ambient temperature and concentrated to dryness under reduced pressure. The residue was diluted with iced water and extracted with ethyl acetate $(2 \times 50 \mathrm{~mL})$. The combined ethyl acetate portions were washed with water and saturated sodium bicarbonate solution. The organic layer was dried over $\mathrm{Na}_{2} \mathrm{SO}_{4}$, filtered and concentrated under reduced pressure to yield a residue which was purified by silica gel column chromatography using 5-40\% EtOAc in hexane to give 2,4-dichloro-5-(4-fluorophenyl)quinazoline $(0.57$ g, $39 \%)$. LCMS $[M+1]=293.6$

2,4-dichloro-5-(4-fluorophenyl)quinazoline $(0.500 \mathrm{~g}, 1.70 \mathrm{mmol})$ was dissolved in THF $(10 \mathrm{~mL})$ and then DIPEA $(0.88 \mathrm{~mL}, 5.1 \mathrm{mmol})$ was added followed by the addition of pyridin-2-ylmethanamine $(0.35 \mathrm{~mL}, 3.4 \mathrm{mmol})$. The reaction mixture was stirred at room temperature for $2 \mathrm{~h}$ then diluted with water $(100 \mathrm{~mL})$. The aqueous portion was extracted with EtOAc $(50 \times 3 \mathrm{~mL})$ and the organic layer was separated, dried over anhydrous sodium sulfate and concentrated under reduced pressure. The residue was purified by silica gel column chromatography using 30-40 \% EtOAc in hexanes as the eluent to afford 2-chloro-5-(4-fluorophenyl)- $\mathrm{N}$-(pyridin-2-ylmethyl)quinazolin4-amine $(0.31 \mathrm{~g}, 50 \%)$. LCMS $[\mathrm{M}+1]=365.2$ 
To a solution of 2-chloro-5-(4-fluorophenyl)- $\mathrm{N}$-(pyridin-2-ylmethyl)quinazolin-4-amine $(0.100 \mathrm{~g}, 0.274 \mathrm{mmol})$ in DME $(5 \mathrm{~mL})$ and water $(0.3 \mathrm{~mL})$ was added $\mathrm{K}_{2} \mathrm{CO}_{3}(0.076 \mathrm{~g}, 0.55 \mathrm{mmol})$, followed by 5-(4,4,5,5-tetramethyl-1,3,2dioxaborolan-2-yl)pyrimidine $(0.085 \mathrm{~g}, 0.41 \mathrm{mmol})$. The reaction mixture was degassed for 5 min with nitrogen and then $\mathrm{Pd}(\mathrm{dppf}) \mathrm{Cl}_{2}(0.010 \mathrm{~g}, 0.013 \mathrm{mmol})$ was added. The resulting slurry was degassed with nitrogen for 5 min and then heated to $110{ }^{\circ} \mathrm{C}$ for $2 \mathrm{~h}$, diluted with water and extracted with dichloromethane. The combined organic layers were dried over sodium sulfate, filtered and concentrated under reduced pressure. The residue was purified by column chromatography using silica gel and eluting the same with $5 \%$ methanol in chloroform to obtain Compound $14 \mathrm{a}(0.056 \mathrm{~g}, 50 \%)$ as an off white solid. ${ }^{1} \mathrm{H}$ NMR (400 MHz, DMSO-d6) $\delta \mathrm{ppm} 9.71(2 \mathrm{H}, \mathrm{s})$, $9.32(1 \mathrm{H}, \mathrm{s}), 8.21(1 \mathrm{H}, \mathrm{d}, J=4.80 \mathrm{~Hz}), 7.71-7.91(3 \mathrm{H}, \mathrm{m}), 7.53-7.58(2 \mathrm{H}, \mathrm{m}), 7.72-7.40(5 \mathrm{H}, \mathrm{m}), 7.05(1 \mathrm{H}, J=$ $3.60 \mathrm{~Hz}), 4.76(2 \mathrm{H}, \mathrm{d}, J=5.20 \mathrm{~Hz}) . \mathrm{LCMS}[\mathrm{M}+1]=409.2$, HPLC Method 1: retention time $8.777 \mathrm{~min}$, Purity $98.5 \%$, HPLC Method 3: retention time 8.372 min, Purity $98.7 \%{ }^{13} \mathrm{C} \mathrm{NMR} \mathrm{(100} \mathrm{MHz,} \mathrm{THF-d)} \delta$ ppm 164.21, 162.25, 159.30, 159.22, 156.27, 156.18, 155.41, 151.59, 148.03, 138.25, 136.83, 136.28, 131.66, 131.33, 131.26, 129.17, 128.52, 121.85, 121.47, 115.88, 115.70, 112.36, 46.13. HRMS 408.1499 (calc) , HRMS [M+1] (obs) 409.1564

\section{Compound 14b:}

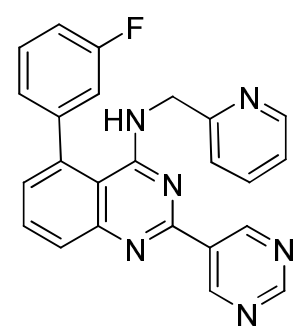

To a mixture of 5-bromoquinazoline-2,4(1H,3H)-dione (1.00 g, $4.14 \mathrm{mmol})$ in DME (15 mL) was added 4fluorophenylboronic acid $(0.87 \mathrm{~g}, 6.2 \mathrm{mmol})$ followed by a solution of sodium carbonate $(1.32 \mathrm{~g}, 12.4 \mathrm{mmol})$ in water $(5 \mathrm{~mL})$ and reaction was purged with nitrogen gas for $15 \mathrm{~min}$. $\mathrm{Pd}(\mathrm{dppf}) \mathrm{Cl}_{2}(0.17 \mathrm{~g}, 0.23 \mathrm{mmol})$ was added to the reaction mixture and nitrogen was passed through the mixture again for $10 \mathrm{~min}$. The reaction mixture was heated at $90{ }^{\circ} \mathrm{C}$ for $48 \mathrm{~h}$, allowed to cool to room temperature and the organic solvent removed under reduced pressure. The residue was diluted with water and the solids were filtered. The solid was azeotroped with $\mathrm{MeOH} / \mathrm{DCM}$ to remove the water and yield 5-(3-fluorophenyl)quinazoline-2,4(1H,3H)-dione $(1.36 \mathrm{~g}, 128 \%)$ as an off-white solid which was taken to the next step without further purification.

5-(3-fluorophenyl)quinazoline-2,4(1H,3H)-dione $\left(1.36 \mathrm{~g}, 5.07 \mathrm{mmol}\right.$ ) was added to $\mathrm{POCl}_{3}(60 \mathrm{~mL}$,$) followed by$ $\mathrm{PhN}\left(\mathrm{CH}_{3}\right)_{2}(1.1 \mathrm{~mL}, 7.61 \mathrm{mmol})$ at ambient temperature. The reaction mixture was heated to reflux $\left(105^{\circ} \mathrm{C}\right)$ for 12 hours then allowed to cool to ambient temperature. The reaction mixture was concentrated to dryness under reduced pressure, diluted with iced water and extracted with ethyl acetate $(2 \times 50 \mathrm{~mL})$. The combined organic portions were washed with water and then with saturated sodium bicarbonate solution. The organic portion was dried over $\mathrm{Na}_{2} \mathrm{SO}_{4}$, filtered and concentrated under reduced pressure to yield a residue which was purified by silica gel column chromatography using 5-40\% EtOAc in hexane to give 2,4-dichloro-5-(3fluorophenyl)quinazoline $(0.52 \mathrm{~g}, 35 \%)$. LCMS [M+1] = 293.4

2,4-dichloro-5-(3-fluorophenyl)quinazoline $(0.500 \mathrm{~g}, 1.70 \mathrm{mmol})$ was dissolved in THF $(10 \mathrm{~mL})$ and then DIPEA $(0.88 \mathrm{~mL}, 5.11 \mathrm{mmol})$ was added followed by the additon of pyridin-2-ylmethanamine $(0.35 \mathrm{~mL}, 3.4 \mathrm{mmol})$. The reaction mixture was stirred at room temperature for $2 \mathrm{~h}$, diluted with water $(100 \mathrm{~mL})$ and the aqueous solution was extracted with EtOAc $(50 \times 3 \mathrm{~mL})$. The combined organic portions were dried over anhydrous sodium sulfate, filtered and concentrated under reduced pressure. The residue was purified by silica gel column 
chromatography using 30-40 \% EtOAc in hexanes as the eluent to afford 2-chloro-5-(3-fluorophenyl)- $\mathrm{N}$-(pyridin2-ylmethyl)quinazolin-4-amine (0.285 g, $45.7 \%)$. LCMS [M+1] = 365.2

To a solution of 2-chloro-5-(3-fluorophenyl)-N-(pyridin-2-ylmethyl)quinazolin-4-amine $(0.100 \mathrm{~g}, 0.274 \mathrm{mmol})$ in DME $(5 \mathrm{~mL})$ and water $(0.3 \mathrm{~mL})$ was added $\mathrm{K}_{2} \mathrm{CO}_{3}(0.076 \mathrm{~g}, 0.55 \mathrm{mmol})$, followed by 5-(4,4,5,5-tetramethyl-1,3,2dioxaborolan-2-yl)pyrimidine $(0.085 \mathrm{~g}, 0.41 \mathrm{mmol})$. The reaction mixture degassed for $5 \mathrm{~min}$ with nitrogen and then $\mathrm{Pd}(\mathrm{dppf}) \mathrm{Cl}_{2}(0.010 \mathrm{~g}, 0.013 \mathrm{mmol})$ was added. The resulting slurry was degassed with nitrogen for $5 \mathrm{~min}$ and then heated to $110^{\circ} \mathrm{C}$ for $2 \mathrm{~h}$, allowed to cool to room temperature, diluted with water and extracted with dichloromethane. The combined organic layers were dried over sodium sulfate, filtered and concentrated under reduced pressure. The residue was purified by column chromatography using silica gel eluting with $5 \%$ methanol in chloroform to obtain Compound $14 \mathrm{~b}(0.048 \mathrm{~g}, 43 \%)$ as an off white solid. ${ }^{1} \mathrm{H} \mathrm{NMR}(400 \mathrm{MHz}$, DMSO-d6) $\delta$ ppm $9.74(2 \mathrm{H}, \mathrm{s}), 9.33(1 \mathrm{H}, \mathrm{s}), 8.27(1 \mathrm{H}, \mathrm{d}, J=4.80 \mathrm{~Hz}), 7.62-7.86(3 \mathrm{H}, \mathrm{m}), 7.58(1 \mathrm{H}, \mathrm{t}, J=14.00$ $\mathrm{Hz}), 7.34-7.48(5 \mathrm{H}, \mathrm{m}), 7.27(1 \mathrm{H}, \mathrm{dd}, J=5.20,6.80 \mathrm{~Hz}), 7.09(1 \mathrm{H}, \mathrm{t}, J=3.60 \mathrm{~Hz}), 4.79(2 \mathrm{H}, \mathrm{d}, J=12.00 \mathrm{~Hz})$. LCMS $[\mathrm{M}+1]=409.2 \mathrm{HPLC}$ Method 3: retention time $8.843 \mathrm{~min}$, Purity 96.7 \% HPLC Method 1: retention time 8.975 min, Purity $95.8 \%{ }^{13} \mathrm{C}$ NMR $(100 \mathrm{MHz}$, THF-d) $\delta$ ppm 157.47, 157.24, 154.43, 153.64, 149.73, 146.21, 140.97, 136.04, 134.40, 129.78, 129.48, 128.89, 128.83, 127.05, 126.90, 123.47, 119.92, 119.56, 114.69, 114.51, 113.16, 113.00, 110.32, 44.26. HRMS 408.1499 (calc) , HRMS [M+1] (obs) 409.1563

\section{Compound 14c:}

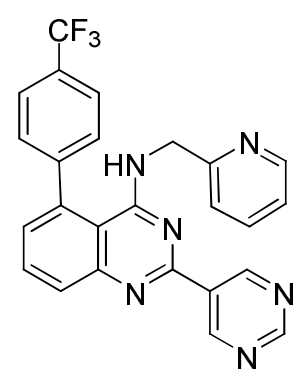

To a mixture of 5-bromoquinazoline-2,4 $(1 \mathrm{H}, 3 \mathrm{H})$-dione $(1.00 \mathrm{~g}, 4.14 \mathrm{mmol})$ in DME $(15 \mathrm{~mL})$ was added 4(trifluoromethyl)phenylboronic acid $(1.18 \mathrm{~g}, 6.21 \mathrm{mmol})$ followed by a solution of sodium carbonate $(1.32 \mathrm{~g}, 12.4$ $\mathrm{mmol})$ in water $(5 \mathrm{~mL})$ and reaction was purged with nitrogen gas for $15 \mathrm{~min}$. $\mathrm{Pd}(\mathrm{dppf}) \mathrm{Cl}_{2}(0.17 \mathrm{~g}, 0.23 \mathrm{mmol})$ was added to the reaction mixture and nitrogen was passed through the mixture again for $10 \mathrm{~min}$. The reaction mixture was heated at $90^{\circ} \mathrm{C}$ for $48 \mathrm{~h}$, then allowed to cool to room temperature and the organic solvent was removed under reduced pressure. The residue was diluted with water and the solid was filtered then azeotroped with $\mathrm{MeOH} / \mathrm{DCM}$ to yield 5-(4-(trifluoromethyl)phenyl)quinazoline-2,4(1H,3H)-dione (1.46 g, $112 \%)$ as an off-white solid which was taken to the next step without further purification.

5-(4-(trifluoromethyl)phenyl)quinazoline-2,4(1H,3H)-dione $(1.4 \mathrm{~g}, 4.5 \mathrm{mmol})$ was added to $\mathrm{POCl}_{3}(60 \mathrm{~mL}$,) followed by $\mathrm{PhN}\left(\mathrm{CH}_{3}\right)_{2}(1.1 \mathrm{~mL}, 6.8 \mathrm{mmol})$ at ambient temperature. The reaction mixture was heated to reflux $\left(105^{\circ} \mathrm{C}\right)$ for 12 hours then allowed to cool to ambient temperature and concentrated to dryness under reduced pressure. The residue was diluted with ice water and extracted with ethyl acetate $(2 \times 50 \mathrm{~mL})$. The combined ethyl acetate layers were washed with water and then with saturated sodium bicarbonate solution, dried over $\mathrm{Na}_{2} \mathrm{SO}_{4}$, filtered and concentrated under reduced pressure to yield a residue. The residue was purified by silica gel column chromatography using 5-40\% EtOAc in hexane to give 2,4-dichloro-5-(4(trifluoromethyl)phenyl)quinazoline (0.65 g, $42 \%$ ). LCMS [M+1] = 344.2 
2,4-dichloro-5-(4-(trifluoromethyl)phenyl)quinazoline $(0.650 \mathrm{~g}, 1.89 \mathrm{mmol})$ was dissolved in THF (20 $\mathrm{mL})$ and then DIPEA (0.97 mL, $5.67 \mathrm{mmol})$ was added followed by pyridin-2-ylmethanamine $(0.400 \mathrm{~mL}, 3.78 \mathrm{mmol})$. The reaction mixture was stirred at room temperature for $2 \mathrm{~h}$, diluted with water $(100 \mathrm{~mL})$ and the aqueous solution was extracted with EtOAc $(50 \times 3 \mathrm{~mL})$. The combined organic portions were dried over anhydrous sodium sulfate, filtered and concentrated under reduced pressure. The residue was purified by silica gel column chromatography using 30-40 \% EtOAc in hexanes as the eluent to afford 2-chloro- $\mathrm{N}$-(pyridin-2-ylmethyl)-5-(4(trifluoromethyl)phenyl)quinazolin-4-amine $(0.37 \mathrm{~g}, 47 \%) .{ }^{1} \mathrm{H} \mathrm{NMR}(400 \mathrm{MHz}, \mathrm{DMSO}-\mathrm{d} 6) \delta \mathrm{ppm} 8.01(1 \mathrm{H}, \mathrm{d}, \mathrm{J}=$ 4.80 Hz), 7.84-7.90 (3 H, m), 7.70-7.76 $(4 \mathrm{H}, \mathrm{m}), 7.22-7.36(3 \mathrm{H}, \mathrm{m}), 7.13(1 \mathrm{H}, \mathrm{t}, J=3.60 \mathrm{~Hz}), 4.58(2 \mathrm{H}, \mathrm{d}, J=3.60$ $\mathrm{Hz})$. LCMS $[\mathrm{M}+1]=415.2$, HPLC Method 1: retention time 19.59 min, Purity 98.6 \%, HPLC Method 3: retention time $16.71 \mathrm{~min}$, Purity $98.6 \%$.

To a solution of 2-chloro-N-(pyridin-2-ylmethyl)-5-(4-(trifluoromethyl)phenyl)quinazolin-4-amine (0.100 g, 0.240 $\mathrm{mmol})$ in DME $(10 \mathrm{~mL})$ and water $(0.5 \mathrm{~mL})$ was added $\mathrm{K}_{2} \mathrm{CO}_{3}(0.066 \mathrm{mg}, 0.48 \mathrm{mmol})$, followed by 5- $(4,4,5,5-$ tetramethyl-1,3,2-dioxaborolan-2-yl)pyrimidine $(0.074 \mathrm{~g}, 0.36 \mathrm{mmol})$. The reaction mixture wasdegassed for 30 min with nitrogen and [1,1'-Bis(diphenylphosphino)ferrocene]dichloropalladium(II), complex with dichloromethane $(0.097 \mathrm{~g}, 0.012 \mathrm{mmol})$ was added. The resulting slurry was degassed with nitrogen for $15 \mathrm{~min}$ and then heated to $110{ }^{\circ} \mathrm{C}$ for $14 \mathrm{~h}$. The reaction mixture was diluted with water and was then extracted with EtOAc $(3 \times 25 \mathrm{~mL})$. The combined organic layers were washed with water and dried over sodium sulfate, filtered and concentrated under reduced pressure. The residue was purified by column chromatography using silica gel (60-120 mesh) eluting with 20-30 \% EtOAc in hexane to obtain Compound 14c (0.045 g, $41 \%$ ) as a off white solid. ${ }^{1} \mathrm{H}$ NMR $(400 \mathrm{MHz}, \mathrm{DMSO}-\mathrm{d6}) \delta \mathrm{ppm} 9.75(2 \mathrm{H}, \mathrm{s}), 9.34(1 \mathrm{H}, \mathrm{s}), 8.09(1 \mathrm{H}, \mathrm{d}, \mathrm{J}=4.80 \mathrm{~Hz}), 7.86-7.96(4 \mathrm{H}$, m), 7.71-7.78 (3 H, m), $7.38(2 \mathrm{H}, \mathrm{d}, J=6.80 \mathrm{~Hz}), 7.24(1 \mathrm{H}, \mathrm{t}, J=5.20 \mathrm{~Hz}), 6.94(1 \mathrm{H}, \mathrm{d}, J=4.00 \mathrm{~Hz}), 4.79(2 \mathrm{H}, \mathrm{d}, J$ $=3.60 \mathrm{~Hz}$ ).LCMS $[\mathrm{M}+1]=459.2$, HPLC Method 1: retention time $10.66 \mathrm{~min}$, Purity $98.4 \%$, HPLC Method 3: retention time $9.933 \mathrm{~min}$, Purity $97.8 \%{ }^{13} \mathrm{C}$ NMR (100 MHz, THF-d) $\delta$ ppm 159.38, 159.03, 156.32, 155.24, 151.67, 147.94, 144.64, 137.73, 136.35, 131.58, 131.48, 130.16, 129.17 (2C), 128.96 (2C), 125.81, 125.77, 121.82, 121.52, 111.99, 46.16. HRMS 458.1467 (calc), HRMS [M+1] (obs) 459.1531

\section{Compound 14d:}<smiles>NC(=O)c1ccc(-c2cccc3nc(-c4cncnc4)nc(NCc4ccccn4)c23)cc1</smiles>

To a solution of 5-bromoquinazoline-2,4-diol (0.500 g, $2.07 \mathrm{mmol})$ in DME (10 mL), DMF (5 mL) and water (5 mL) was added $\mathrm{Na}_{2} \mathrm{CO}_{3}(0.660 \mathrm{mg}, 6.20 \mathrm{mmol})$, followed by methyl 4-(4,4,5,5-tetramethyl-1,3,2-dioxaborolan-2$\mathrm{yl}$ )benzoate $(0.816 \mathrm{~g}, 3.11 \mathrm{mmol})$. The reaction mixture degassed for $30 \mathrm{~min}$ with nitrogen and then [1,1'Bis(diphenylphosphino)ferrocene] dichloropalladium(II), complex with dichloromethane $(0.085 \mathrm{~g}, 0.010 \mathrm{mmol})$ was added. The resulting slurry was degassed with nitrogen for $15 \mathrm{~min}$ and then heated to $110^{\circ} \mathrm{C}$ for $14 \mathrm{~h}$. The reaction mixture was diluted with water and was then extracted with EtOAc ( $3 \times 25 \mathrm{~mL})$. The combined organic layers were washed with water and dried over sodium sulfate, filtered and concentrated under reduced pressure. The residue was purified by column chromatography using silica gel (60-120 mesh) eluting with $5 \%$ 
$\mathrm{MeOH}$ in chloroform to obtain methyl 4-(2,4-dihydroxyquinazolin-5-yl)benzoate $(0.800 \mathrm{~g}, 129 \%)$ as a off white solid. $L C M S[M+1]=297.2$

Methyl 4-(2,4-dihydroxyquinazolin-5-yl)benzoate $(0.800 \mathrm{~g}, 2.70 \mathrm{mmol})$ was added to $\mathrm{POCl}_{3}(48 \mathrm{~mL})$ followed by $\mathrm{PhN}\left(\mathrm{CH}_{3}\right)_{2}(0.63 \mathrm{~mL}, 4.05 \mathrm{mmol})$ at ambient temperature. The reaction mixture was heated to reflux $\left(105^{\circ} \mathrm{C}\right)$ for 16 hours, allowed to cool to ambient temperature and was concentrated to dryness under reduced pressure. The residue was coevaporated with toluene, diluted with ice water and extracted with ethyl acetate (2x50 $\mathrm{mL})$. The combined ethyl acetate layers were washed with saturated sodium bicarbonate solution, ,dried over $\mathrm{Na}_{2} \mathrm{SO}_{4}$, filtered and concentrated under reduced pressure to yield a residue. The residue was purified by silica gel (60 - 120) column chromatography using $2 \%$ methanol in chloroform to obtain methyl 4-(2,4dichloroquinazolin-5-yl)benzoate as a brown solid (0.450 g, $49.9 \%) . \mathrm{LCMS}[\mathrm{M}+1]=333.0$

Methyl 4-(2,4-dichloroquinazolin-5-yl)benzoate $(0.450 \mathrm{~g}, 1.35 \mathrm{mmol})$ was dissolved in THF $(6 \mathrm{~mL})$ and pyridin-3ylmethanamine $(0.280 \mathrm{~mL}, 2.71 \mathrm{mmol})$ added. The reaction mixture was stirred at room temperature for $3 \mathrm{~h}$ and diluted with water $(50 \mathrm{~mL})$. The aqueous solution was extracted with EtOAc $(50 \times 2 \mathrm{~mL})$ and the combined organic layers washed with brine, dried over anhydrous sodium sulfate, filtered and was concentrated under reduced pressure. The residue was purified by silica gel (60-120) column chromatography using $1 \%$ methanol in chloroform to afford solid methyl 4-(2-chloro-4-(pyridin-2-ylmethylamino)quinazolin-5-yl)benzoate (0.300 g, $54.0 \%) .{ }^{1} \mathrm{H}$ NMR (400 MHz, DMSO-d6) $\delta \mathrm{ppm} 8.08(2 \mathrm{H}, \mathrm{d}, J=1.60 \mathrm{~Hz}), 7.87-7.94(2 \mathrm{H}, \mathrm{m}), 7.64-7.76(4 \mathrm{H}, \mathrm{m})$, 7.34-7.36 $(2 \mathrm{H}, \mathrm{m}), 7.22(1 \mathrm{H}, \mathrm{dd}, J=5.20,6.40 \mathrm{~Hz}), 7.09(1 \mathrm{H}, \mathrm{s}), 4.57(2 \mathrm{H}, \mathrm{d}, J=4.00 \mathrm{~Hz}), 3.95(3 \mathrm{H}, \mathrm{s})$. LCMS $[\mathrm{M}+1]=405.0$

To a solution of methyl 4-(2-chloro-4-(pyridin-2-ylmethylamino)quinazolin-5-yl)benzoate $(0.30 \mathrm{~g}, 0.74 \mathrm{mmol})$ in DME $(10 \mathrm{~mL})$ and water $(0.5 \mathrm{~mL})$ was added $\mathrm{K}_{2} \mathrm{CO}_{3}(0.20 \mathrm{mg}, 1.4 \mathrm{mmol})$, followed by 5-(4,4,5,5-tetramethyl1,3,2-dioxaborolan-2-yl)pyrimidine $(0.229 \mathrm{~g}, 0.140 \mathrm{mmol})$. The reaction mixture degassed for $30 \mathrm{~min}$ with nitrogen and then [1,1'-Bis(diphenylphosphino)ferrocene] dichloropalladium(II)(0.026 g, $0.035 \mathrm{mmol})$ was added. The resulting slurry was degassed with nitrogen for $15 \mathrm{~min}$ and then heated to $110{ }^{\circ} \mathrm{C}$ for $14 \mathrm{~h}$. The reaction mixture was diluted with water and was then extracted with EtOAc ( $3 \times 50 \mathrm{~mL})$. The combined organic layers were washed with water and dried over sodium sulfate, filtered and concentrated under reduced pressure. The residue was purified by column chromatography using silica gel (60-120 mesh) and eluting the same with $1 \% \mathrm{MeOH}$ in chloroform to obtain methyl 4-(4-(pyridin-2-ylmethylamino)-2-(pyrimidin-5-yl) quinazolin-5-yl) benzoate $(0.33 \mathrm{~g}, 99 \%)$ as an off white solid. ${ }^{1} \mathrm{H}$ NMR $(400 \mathrm{MHz}, D M S O-d 6) \delta \mathrm{ppm} 9.74(2 \mathrm{H}, \mathrm{s})$, $9.34(1 \mathrm{H}, \mathrm{s}), 8.07(2 \mathrm{H}, \mathrm{dd}, J=4.40,40.00 \mathrm{~Hz}), 7.87-7.96(3 \mathrm{H}, \mathrm{m}), 7.67-7.75(3 \mathrm{H}, \mathrm{m}), 7.37-7.39(2 \mathrm{H}, \mathrm{m}), 7.22-$ $7.25(1 \mathrm{H}, \mathrm{m}), 6.89(1 \mathrm{H}, \mathrm{s}), 4.77(2 \mathrm{H}, \mathrm{d}, J=4.00 \mathrm{~Hz}), 3.96(3 \mathrm{H}, \mathrm{s}) . \mathrm{LCMS}[\mathrm{M}+1]=449.2$, HPLC Method 1: retention time 7.99 min, Purity $97.2 \%$, HPLC Method 3: retention time 7.92 min, Purity $98.4 \%$

To a stirred solution of methyl 4-(4-(pyridin-2-ylmethylamino)-2-(pyrimidin-5-yl)quinazolin-5-yl)benzoate (340 $\mathrm{mg}, 0.74 \mathrm{mmol})$ in methanol $(5 \mathrm{~mL})$ and THF $(5 \mathrm{~mL})$ was added LiOH $(0.0941 \mathrm{~g}, 2.24 \mathrm{mmol})$ in water $(1 \mathrm{~mL})$. THF $(5 \mathrm{~mL})$ was further added to make reaction homogenous. The mixture was stirred for $16 \mathrm{~h}$ at room temperature. $1.5 \mathrm{~N} \mathrm{HCl}$ was added so that $\mathrm{pH}$ was adjusted to 4-5. A solid separated from reaction mixture and was filtered and washed with water and hexane to yield 4-(4-(pyridin-2-ylmethylamino)-2-(pyrimidin-5-yl)quinazolin-5yl)benzoic acid $\left(0.160 \mathrm{~g}, 48 \%\right.$ ). ${ }^{1} \mathrm{H}$ NMR $(400 \mathrm{MHz}, \mathrm{DMSO}-d 6) \delta \mathrm{ppm} 13.18(1 \mathrm{H}, \mathrm{s}), 9.73(1 \mathrm{H}, \mathrm{s}), 9.33(1 \mathrm{H}, \mathrm{s})$, 8.05-8.11 (3 H, m), 7.85-7.94 (2 H, m), 7.71-7.75 (3 H, m), 7.36-7.66 (2 H, m), 7.22 (2 H, dd, J = 5.20, 7.20 Hz), $6.97(1 \mathrm{H}, \mathrm{s}), 4.76(2 \mathrm{H}, \mathrm{dd}, J=3.60, \mathrm{~Hz}) . \mathrm{LCMS}[\mathrm{M}+1]=435.2$, HPLC Method 1: retention time 6.31 min, Purity $95.3 \%$, HPLC Method 3: retention time 6.53 min, Purity $96.9 \%$ 
To a solution of 4-(4-(pyridin-2-ylmethylamino)-2-(pyrimidin-5-yl)quinazolin-5-yl)benzoic acid (0.050 g, 0.11 mmol) in DMF ( $3 \mathrm{~mL}$ ) was added HOBT $(0.019 \mathrm{~g}, 0.13 \mathrm{mmol})$, EDC hydrochloride $(0.027 \mathrm{~g}, 0.13 \mathrm{mmol})$, and ammonium chloride $(0.025 \mathrm{~g}, 0.46 \mathrm{mmol})$. The suspension was stirred for $15 \mathrm{~min}$, DIPEA $(0.178 \mathrm{~mL}, 0.46 \mathrm{mmol})$ was added and the reaction mixture was stirred for $18 \mathrm{~h}$. DMF was removed under reduced pressure and the residue was triturated with water $(25 \mathrm{~mL})$. The resulting precipitate was filtered and further washed with water $(50 \mathrm{~mL})$ then purified by column chromatography using silica gel (60-120 mesh) eluting with $1 \% \mathrm{MeOH}$ in chloroform to obtain Compound 14d (0.028 g, $56 \%$ ). ${ }^{1} \mathrm{H}$ NMR (400 MHz, DMSO-d6) $\delta$ ppm $9.75(2 \mathrm{H}, \mathrm{d}, J=0.80$ $\mathrm{Hz}), 9.35(1 \mathrm{H}, \mathrm{d}, J=0.80 \mathrm{~Hz}), 7.86-8.14(6 \mathrm{H}, \mathrm{m}), 7.73(1 \mathrm{H}, \mathrm{t}, J=7.60 \mathrm{~Hz}), 7.53-7.63(3 \mathrm{H}, \mathrm{m}), 7.37(1 \mathrm{H}, \mathrm{t}, J=6.80$ $\mathrm{Hz}), 7.21(1 \mathrm{H}, \mathrm{t}, J=6.40 \mathrm{~Hz}), 7.09(1 \mathrm{H}, \mathrm{s}), 4.78(2 \mathrm{H}, \mathrm{d}, J=3.60 \mathrm{~Hz})$. LCMS [M+1] = 434.2, HPLC Method 1: retention time $5.29 \mathrm{~min}$, Purity $97.3 \%$, HPLC Method 3: retention time 5.59 min, Purity $97.89 \%{ }^{13} \mathrm{C} \mathrm{NMR}$ (100 $\mathrm{MHz}$, THF-d) $\delta$ ppm 159.05, 157.46, 154.43, 149.74, 146.59, 138.78, 134.26, 130.43, 129.49, 127.24 (2C), 126.40 (2C), 119.87, 119.31, 118.78, 112.93, 44.38. HRMS 433.1651 (calc), HRMS [M+1] (obs) 434.1715

\begin{tabular}{|c|c|c|c|c|c|}
\hline Condition & Column & Solvent A & Solvent B & Method & $\begin{array}{c}\text { Wavelength } \\
\text { (nm) }\end{array}$ \\
\hline 1 & $\begin{array}{l}\text { Sunfire C18, } 4.6 \\
\text { X150 mm, } 3.5 \\
\mu \mathrm{m}\end{array}$ & $\begin{array}{l}0.05 \% \text { TFA in } \\
\mathrm{H}_{2} \mathrm{O}(\mathrm{pH} 2.5, \\
\text { adjusted with } \\
\text { dilute } \\
\text { ammonia), 95\% } \\
\text { acetonitrile, 5\% } \\
\text { water }\end{array}$ & $\begin{array}{l}0.05 \% \text { TFA in } \\
\text { H2O (pH 2.5, } \\
\text { adjusted with } \\
\text { dilute } \\
\text { ammonia), } 5 \% \\
\text { acetonitrile, } \\
95 \% \text { water }\end{array}$ & $\begin{array}{l}\text { Start } \% B=10 ; \\
\text { Final } \% B=100, \\
\text { gradient time } \\
=12 \text { min; Stop } \\
\text { time = } 23 \text { min } \\
\text { Isocratic time } \\
=3 \text { min } \\
\text { Flow Rate = } 1 \\
\mathrm{~mL} / \mathrm{min} \text { flow } \\
\text { rate }\end{array}$ & 220,254 \\
\hline 2 & $\begin{array}{l}\text { XBridge, } 4.6 \mathrm{X} \\
150 \mathrm{~mm}, 3.5 \\
\mu \mathrm{m}\end{array}$ & $\begin{array}{l}0.05 \% \text { TFA in } \\
\mathrm{H}_{2} \mathrm{O}(\mathrm{pH} 2.5, \\
\text { adjusted with } \\
\text { dilute } \\
\text { ammonia), 95\% } \\
\text { acetonitrile, 5\% } \\
\text { water }\end{array}$ & $\begin{array}{l}0.05 \% \text { TFA in } \\
\text { H2O (pH 2.5, } \\
\text { adjusted with } \\
\text { dilute } \\
\text { ammonia), } 5 \% \\
\text { acetonitrile, } \\
95 \% \text { water }\end{array}$ & $\begin{array}{l}\text { Start } \% B=10 ; \\
\text { Final } \% B=100, \\
\text { gradient time } \\
=12 \text { min; Stop } \\
\text { time = } 18 \text { min } \\
\text { Isocratic time } \\
=3 \text { min } \\
\text { Flow Rate = } 1 \\
\mathrm{~mL} / \mathrm{min} \text { flow } \\
\text { rate }\end{array}$ & 220,254 \\
\hline 3 & $\begin{array}{l}\text { Xbridge phenyl, } \\
4.6 \text { X } 150 \mathrm{~mm} \text {, } \\
3.5 \mu \mathrm{m}\end{array}$ & $\begin{array}{l}0.05 \% \text { TFA in } \\
\mathrm{H}_{2} \mathrm{O}(\mathrm{pH} 2.5, \\
\text { adjusted with } \\
\text { dilute } \\
\text { ammonia), 95\% } \\
\text { acetonitrile, 5\% } \\
\text { water }\end{array}$ & $\begin{array}{l}0.05 \% \text { TFA in } \\
\mathrm{H} 2 \mathrm{O}(\mathrm{pH} 2.5, \\
\text { adjusted with } \\
\text { dilute } \\
\text { ammonia), 5\% } \\
\text { acetonitrile, } \\
95 \% \text { water }\end{array}$ & $\begin{array}{l}\text { Start } \% B=10 ; \\
\text { Final } \% B=100, \\
\text { gradient time } \\
=25 \mathrm{~min} ; \text { Stop } \\
\text { time = } 30 \text { min } \\
\text { Isocratic time } \\
=5 \mathrm{~min}\end{array}$ & 220,254 \\
\hline
\end{tabular}




\begin{tabular}{|c|c|c|c|c|c|}
\hline & & & & $\begin{array}{l}\text { Flow Rate }=1 \\
\mathrm{~mL} / \mathrm{min} \text { flow } \\
\text { rate }\end{array}$ & \\
\hline 4 & $\begin{array}{l}\text { X-Bridge } \\
\text { Phenyl, } 4.6 \text { X } \\
150 \mathrm{~mm}, 3.5 \\
\mu \mathrm{m}\end{array}$ & $\begin{array}{l}10 \mathrm{mM} \\
\mathrm{NH}_{4} \mathrm{OAc} \text { in } \mathrm{H}_{2} \mathrm{O} \\
\text { (pH 5.0), water }\end{array}$ & $\begin{array}{l}10 \mathrm{mM} \\
\mathrm{NH}_{4} \mathrm{OAc} \text { in } \mathrm{H}_{2} \mathrm{O} \\
\text { (pH 5.0), } \\
\text { methanol }\end{array}$ & $\begin{array}{l}\text { Start } \% B=70 ; \\
\text { Final } \% B=100, \\
\text { gradient time } \\
=4 \text { min; Stop } \\
\text { time = } 20 \text { min } \\
\text { Isocratic time } \\
=3 \text { min } \\
\text { Flow Rate = } 1 \\
\mathrm{~mL} / \mathrm{min} \text { flow } \\
\text { rate }\end{array}$ & 220 \\
\hline 5 & $\begin{array}{l}\text { Phenomenex }^{\circledR} \\
\text { Luna, C18 4.6 X } \\
30 \mathrm{~mm}\end{array}$ & $\begin{array}{l}0.1 \% \\
\text { trifluoroacetic } \\
\text { acid, } 90 \% \\
\text { water, } 10 \% \\
\text { acetonitrile }\end{array}$ & $\begin{array}{l}0.1 \% \\
\text { trifluoroacetic } \\
\text { acid, } 90 \% \\
\text { acetonitrile, } \\
10 \% \text { water }\end{array}$ & $\begin{array}{l}\text { Linear gradient } \\
\text { of } 0 \text { to } 100 \% \text { B } \\
\text { over } 2 \text { min, } \\
\text { with } 3 \text { min } \\
\text { hold at } 100 \% \text { B } \\
\text { Flow Rate = } 5 \\
\mathrm{~mL} / \mathrm{min} \text { flow } \\
\text { rate }\end{array}$ & 220 \\
\hline 6 & $\begin{array}{l}\text { X-Bridge } \\
\text { Phenyl, } 4.6 \mathrm{X} \\
150 \mathrm{~mm}, 3.5 \\
\mu \mathrm{m}\end{array}$ & $\begin{array}{l}0.1 \% \\
\text { trifluoroacetic } \\
\text { acid, } 90 \% \\
\text { water, } 10 \% \\
\text { acetonitrile }\end{array}$ & $\begin{array}{l}0.1 \% \\
\text { trifluoroacetic } \\
\text { acid, } 90 \% \\
\text { acetonitrile, } \\
10 \% \text { water }\end{array}$ & $\begin{array}{l}\text { Linear gradient } \\
\text { of } 0 \text { to } 100 \% \text { B } \\
\text { over } 10 \mathrm{~min} \text {, } \\
\text { with } 5 \text { min } \\
\text { hold at } 100 \% \text { B } \\
\text { Flow Rate = } 1 \\
\mathrm{~mL} / \mathrm{min} \text { flow } \\
\text { rate }\end{array}$ & 220 \\
\hline 7 & $\begin{array}{l}\text { Waters BEH } \\
\text { C18 } 2.1 \times 50 \\
\mathrm{~mm}\end{array}$ & $\begin{array}{l}0.05 \% \text { TFA, } \\
100 \% \text { water }\end{array}$ & $\begin{array}{l}0.05 \% \text { TFA, } \\
100 \% \text { ACN }\end{array}$ & $\begin{array}{l}\text { Linear gradient } \\
\text { of } 2 \text { to } 98 \% \text { B } \\
\text { over } 1 \mathrm{~min}, \\
\text { with } 0.5 \mathrm{~min} \\
\text { hold time at } \\
98 \% \text { B Flow } \\
\text { Rate }=0.8 \\
\mathrm{~mL} / \mathrm{min} \text { flow } \\
\text { rate }\end{array}$ & 220 \\
\hline 8 & $\begin{array}{l}\text { Supelco } \\
\text { Ascentis } \\
\text { Express C18 } 4.6 \\
\text { x } 50 \mathrm{~mm}, 2.7 \\
\mu \mathrm{m}\end{array}$ & $\begin{array}{l}0.05 \% \text { TFA, } \\
95 \% \text { water, } 5 \% \\
\text { methanol }\end{array}$ & $\begin{array}{l}0.05 \% \text { TFA, } 5 \% \\
\text { water, } 95 \% \\
\text { methanol }\end{array}$ & $\begin{array}{l}\text { Linear gradient } \\
\text { of } 0 \text { to } 100 \% \text { B } \\
\text { over } 4 \text { min, } \\
\text { with } 1 \text { min } \\
\text { hold time at } \\
100 \% \text { B Flow } \\
\text { Rate = } 4 \\
\mathrm{~mL} / \mathrm{min} \text { flow }\end{array}$ & 220 \\
\hline
\end{tabular}




\begin{tabular}{|l|l|l|l|l|}
\hline & & & rate & \\
\hline
\end{tabular}

